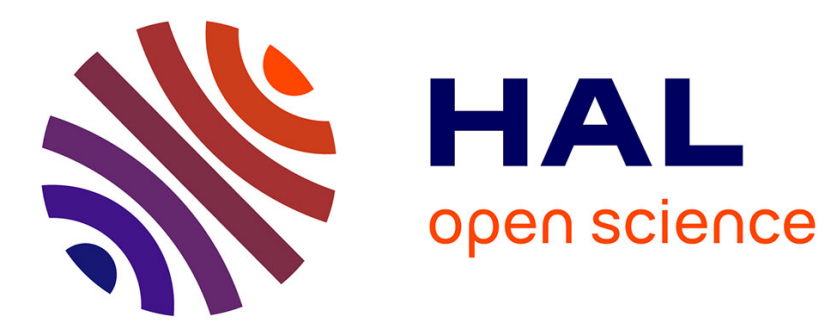

\title{
2,4-Substituted bispidines as rigid hosts for versatile applications: from $\kappa$-opioid receptor to metal coordination
}

\author{
Aline M. Nonat, Amandine Roux, Maryame Sy, Loic J Charbonniere
}

\section{To cite this version:}

Aline M. Nonat, Amandine Roux, Maryame Sy, Loic J Charbonniere. 2,4-Substituted bispidines as rigid hosts for versatile applications: from $\kappa$-opioid receptor to metal coordination. Dalton Transactions, 2019, 48 (44), pp.16476-16492. 10.1039/c9dt03480c . hal-02439628

\section{HAL Id: hal-02439628 \\ https://hal.science/hal-02439628}

Submitted on 16 Sep 2020

HAL is a multi-disciplinary open access archive for the deposit and dissemination of scientific research documents, whether they are published or not. The documents may come from teaching and research institutions in France or abroad, or from public or private research centers.
L'archive ouverte pluridisciplinaire HAL, est destinée au dépôt et à la diffusion de documents scientifiques de niveau recherche, publiés ou non, émanant des établissements d'enseignement et de recherche français ou étrangers, des laboratoires publics ou privés. 


\section{Journal Name}

\section{ARTICLE}

\section{2,4-substituted bispidines as rigid hosts for versatile applications: from $\boldsymbol{k}$-opioid receptor to metal coordination}

Received 00th January 20xx, Accepted 00th January 20xx

DOI: $10.1039 / x 0 x \times 00000 x$

www.rsc.org/

\begin{abstract}
Aline M. Nonat, ${ }^{a \mathrm{a}}$ Amandine Roux, ${ }^{\mathrm{a}, \mathrm{b}}$ Maryame Sy, ${ }^{\mathrm{a}}$ and Loïc J. Charbonnière ${ }^{\mathrm{a}}$
Bispidones (3,7-diazabicyclo[3.3.1]nonan-9-one) are bicyclic analogues of the natural antiarrythmic agent, spartein. They can straightforwardly be obtained from two successive Mannich reactions. Reduction of the ketone gives the corresponding bispidol. Substituted bispidones and bispidols offer a large playground by varying the substituents, the configuration of the carbon atoms in position 2 and 4 as well as the conformation of the bicycle. While chair-boat conformers display a strong affinity for k-opioid receptors, chair-chair bispidines provide adaptable coordination spheres for transition metal and rare-earth ions. Because of their very rich coordination chemistry, substituted bispidines have emerged in various applications of coordination chemistry, such as catalysis, magnetism and medical imaging.
\end{abstract}

\section{A. Introduction}

The bispidine scaffold (3,7-diazabicyclo[3.3.1]nonane) is formed by two fused cyclohexylamine rings. Bispidine derivatives are naturally occurring in plants such as Genista (as ( $7 \alpha-9 \alpha)$-spartein) or Lupinus species ((+)-lupanine), which have been used for therapeutic purposes since the Middle-Age and also by southwestern American Indian tribes for their antiarrhythmic and antihypertensive properties ('Purple smoke') or, in the case of Genistae, as uterine stimulant. Such plants are still used in traditional Chinese medicine. The structures of so-called bispidone and bispidol compounds, as well as their IUPAC numbering, are presented in Figure 1.

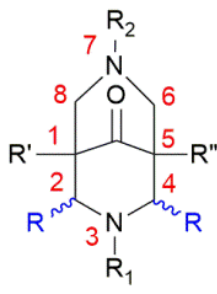

Bispidone

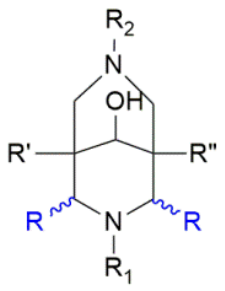

Bispidol
Figure 1: General structure of 2,4-disubstituted bispidine and their IUPAC numbering.
The research on bispidine derivatives has emerged following the discovery of the natural product spartein and its cardiac antiarrhythmic properties by Stenhouse in $1851 .{ }^{1}$ Since then, first reports were focused on their synthesis by a variant of the Mannich condensation ${ }^{2}$ and on the study of their biological activity. ${ }^{3}$ The field started to expand exponentially in the late 90's and the introduction of aryl substituents in the $\mathrm{C} 2$ and $\mathrm{C} 4$ position has played a determining role for this take off (around 150 articles and 1050 citations on 1,4-substituted bispidines). In the late 90's, Holzgrabe and his collaborators have demonstrated the strong affinity and selectivity of dimethyl 3,7-methyl-2,4-di-2-pyridyl-3,7diazabicyclo[3.3.1]nonan-9-one-1,5-dicarboxylate $\left(L_{1}\right.$, Figure 5$)$ for K-opioid receptors. ${ }^{4}$ At the same time, the work of Comba, Wadepohl, Pritzkow and Kerscher has demonstrated that the rigid skeleton of 2,4-disubstituted bispidine is an ideal platform for the coordination of most transition metals. ${ }^{5}$ In particular, the denticity of the ligand can be tuned with the substituents of the bispidine backbone in order to accommodate coordination numbers form $\mathrm{CN}=5$ to $\mathrm{CN}=9$ offering potential applications in a wide range of coordination complexes involving different types of metal ions of the $s, p, d$ and $f$ block elements. This tutorial review is focused on bispidine with substituents at positions $\mathrm{C} 2$ and $\mathrm{C} 4$ and will describe their synthesis and stereochemistry, their reactivity and their main coordination properties. Finally, selected examples of applications in the fields of catalysis, molecular magnetism and positron emission imaging will be presented.

\footnotetext{
a. Equipe de Synthèse pour l'Analyse (SynPA), Institut Pluridisciplinaire hubert Curien (IPHC, UMR 7178), CNRS/université de Strasbourg, ECPM, 25 rue Becquerel, 67087 Strasbourg Cedex, France

b. Université de Lyon, ENS Lyon, CNRS, Université Lyon 1, Laboratoire de Chimie, UMR 5182, 46 allée d'Italie, 69364 Lyon, France.
} 


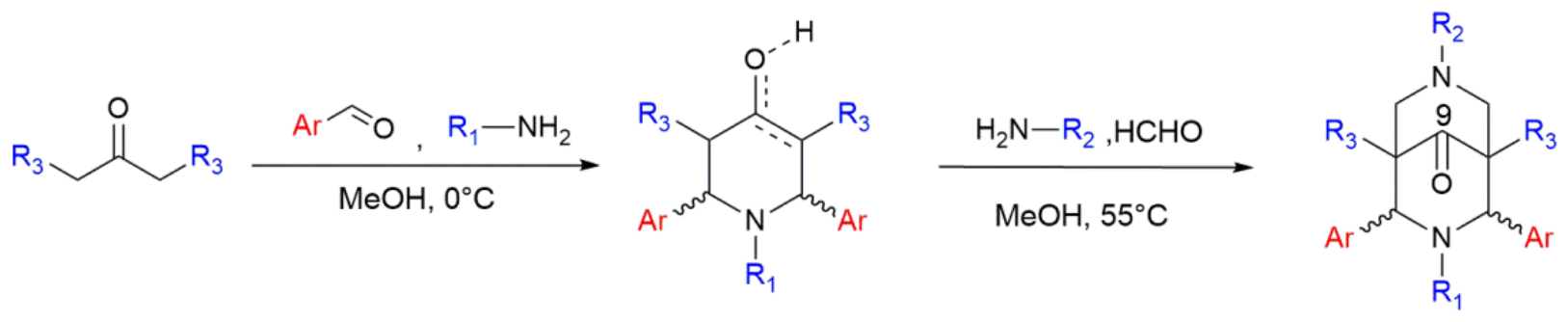

Figure 2: General synthesis of bispidones.

\section{B. Synthesis, stereochemistry and reactivity of 2,4-substituted bispidones}

1. Synthesis and stereochemistry

2,4-disubstituted bispidones (Figure 2 ) are readily obtained in two steps, each one involving two successive Mannich reactions. ${ }^{2}$ Historically, 2,4-pyridyl substituted bispidones have been synthesized by the group of Haller ${ }^{6}$ and Caujolle ${ }^{7}$ in the 70's and Holzgrabe in the late 90 's. ${ }^{8}$ At first, piperidone (also called piperidinone) intermediates are obtained by reaction of dimethyl1,3-acetonedicarboxylate, 2-pyridinecarboxaldehyde, and a primary amine $\mathrm{R}_{1}-\mathrm{NH}_{2}$. Then, these piperidones are reacted with formaldehyde and a second primary amine $\mathrm{R}_{2}-\mathrm{NH}_{2}$ to obtain the corresponding bispidone (Figure 2).

Noteworthy, important variability is observed in the global yield of these two steps, which is often limited by the formation of the second ring (with yields ranging from 5 to $91 \%$ ).

The piperidone precursor can exist as a cis or trans isomer depending on the relative position of the pyridyl groups (Figure 3). Furthermore, keto-enol equilibrium is also possible for both forms leading to four isomers (cis-enol, cis-ketone, trans-ketone and trans-enol) in solution. The proportion of each will mainly depend on the experimental conditions and on the nature of the $R_{1}$ substituent. A mixture of isomers is often used without purification for the formation of the bispidone, which is isolated in one of the three following conformations: chair-chair (cc), chair-boat (cb) or

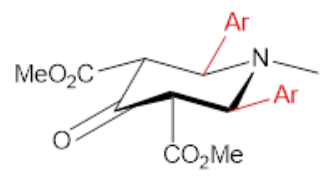

cis-ketone

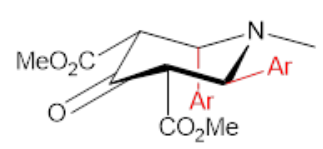

trans-ketone

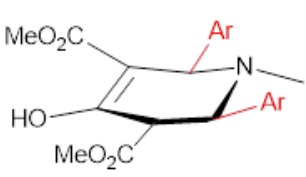

cis-enol

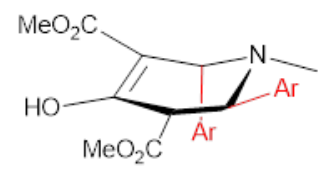

trans-enol
Figure 3: Potential isomers of the piperidone intermediate. boat-chair (bc) (Figure 4). The boat-boat conformation (bb) is energetically unfavourable.

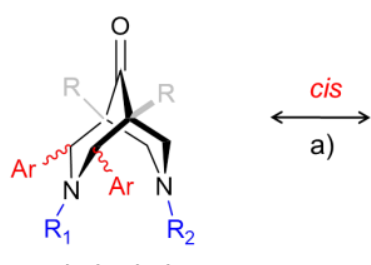

chair-chair

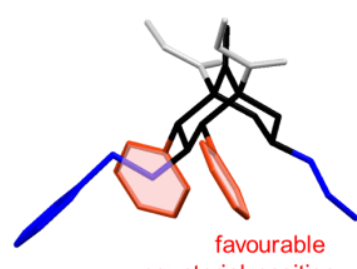

equatorial position

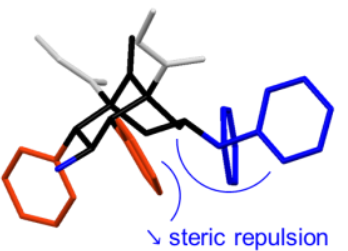

b)

$\searrow$ steric repulsion

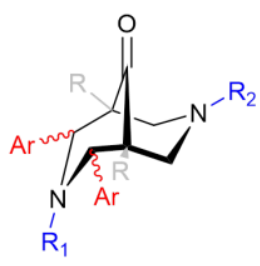

chair-boat

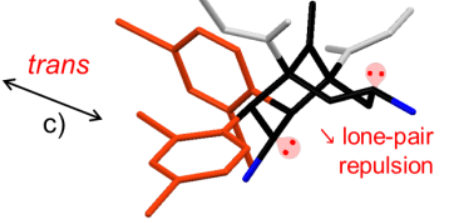

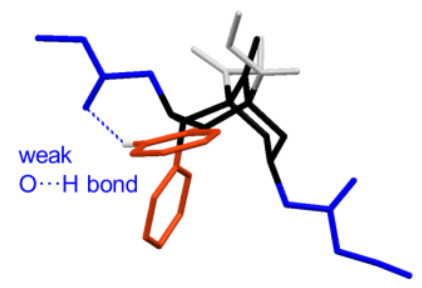

boat-chair

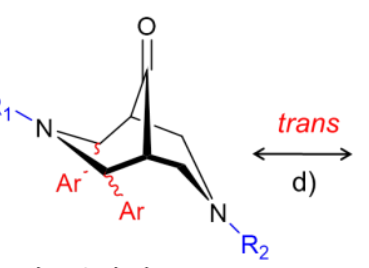

Figure 4: Illustration of the possible conformations/configurations of 2,4-substituted bispidones with X-ray structures: a) cis-chair-chair ${ }^{7}$, b) cis-chair-boat $^{13}$, c) trans-chair-boat ${ }^{14}$, d) trans-boatchair $^{9}$.

Structural analysis by X-ray diffraction have been done historically by Caujolle and al. ${ }^{7}$ Crystallographic data showed chair-chair conformation of the bicyclic system in which the phenyl substituents at $\mathrm{C} 2$ and $\mathrm{C} 4$ are located in the equatorial position, hence providing a cis-symmetrical configuration (Figure 4a). The chair-chair conformation of the bicyclic ring is only a little affected by substitution (slightly flattened) and is characterized by a typical N3-N7 distance of $2.891 \AA$, whereas the expected distance for an 
ideal chair-chair conformation is around $2.83 \AA$. Moreover, the plane defined by N3, N7 and C9 can be considered as a plane of symmetry for the bispidone ring. In addition to X-ray diffraction on monocrystals, ${ }^{1} \mathrm{H}$ NMR studies in solution can be used to determine the cis/trans configuration of the substituents at $\mathrm{C} 2$ and $\mathrm{C} 4$, by using the chemical shifts of protons of interest $(\mathrm{H} 2, \mathrm{H} 4, \mathrm{H} 6, \mathrm{H} 8$ and those on aromatic substituents). ${ }^{6}$ Whereas bispidones in the cischair-boat configuration are characterized by a $\mathrm{C}_{\mathrm{S}}$ symmetry, transchair-boat isomers give rise to two sets of signals in ${ }^{1} \mathrm{H} /{ }^{13} \mathrm{C} \mathrm{NMR}$. Moreover, the trans configuration can be confirmed by ${ }^{1} \mathrm{H}-{ }^{1} \mathrm{H}$ NOESY experiments in which the $\mathrm{H} 4$ proton in the axial position give a strong positive NOE effect with the $\mathrm{H} 6$ protons in equatorial position (Figure $4 \mathrm{~d}$ ). ${ }^{6,9}$ In some cases, negative NOE effect is also observed with the $\mathrm{H} 8$ protons in equatorial position due to the $\mathrm{W}$ conformation between the two protons. ${ }^{10} \mathrm{H} 2$ protons in axial position are not expected to give any interactions.

Among the many 1,5-diester, 2,4-diaryl substituted bispidones reported in the literature (more than 100), most of them were isolated in a symmetrical chair-chair conformation of the bicyclic ring system, with the aryl substituents in equatorial position. This is the case when a methyl group or a proton are introduced at N3. As a consequence, the position N7 has been used in order to introduce additional donors for metal coordination. A library of disubstituted bispidones with methylpyridine and quinoline substituents has been synthesized by Comba and coworkers ${ }^{5,11}$ whereas Nonat and Charbonnière have worked on the introduction of glycinate and methanephosphonate functions. ${ }^{9,10,12}$ The structures of all mononuclear ligands discussed in the text are given in Figure 5. A detailed table of the various bispidones isolated to date is given in the review of Comba. ${ }^{11}$

Only few examples have been isolated in the chair-boat or boatchair configuration. Chair-boat conformations are obtained when a large substituent (such as 2-benzylpyridyl) is introduced at N7 (Figure $4 \mathrm{~b}) .{ }^{13}$ However, coordination of the nitrogen atoms N7 and of the pyridyl group drives the formation of a complex with a chairchair conformation. More recently, another structure showing the chair-boat isomer was obtained with a dibromopyridine substituted bispidone. ${ }^{14}$ In this case, the size of the substituent in $\mathrm{C} 2$ and $\mathrm{C} 4$ positions induces a trans configuration of the dibromopyridine units and forced the N3 nitrogen to adopt a trigonal geometry inducing a stronger repulsion of the unbounded doublets of the two nitrogens (Figure 4c) ${ }^{14}$ The lone-pair repulsion of N3 and N7 is avoided by adopting the chair-boat conformation. It appears that the introduction of bulky substituents ${ }^{15}$ or hydrogen bond accepting groups $^{9}$ on N3 induces a trans configuration of the $\mathrm{C} 2 / \mathrm{C} 4$ substituents associated with a boat-chair conformation (Figure $4 d$ ). Boat-boat conformation has only been observed with unsubstituted bispidones. ${ }^{16}$ Finally, restricted rotation of the C2/C4 substituents has been reported with polysubstituted arenes, quinolyl, naphtyl and imidazolyl derivatives, therefore adding supplementary isomers. For example, pyridyl nitrogen can point towards the upper part of the molecule, i.e. towards the ketone, or towards the lower part of the molecule, i.e. towards the $R_{1}$ group. All these conformations are possible but not always observable because the

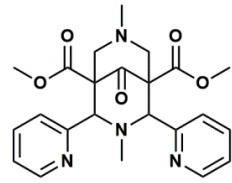

$\mathrm{L}_{1}$

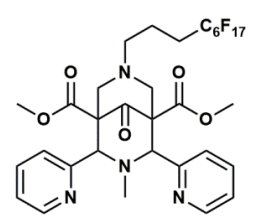

$\mathbf{L}_{6}$

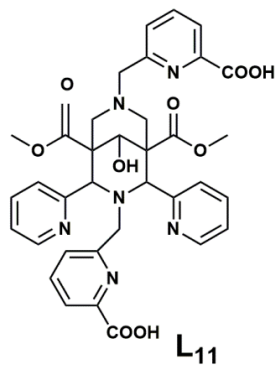

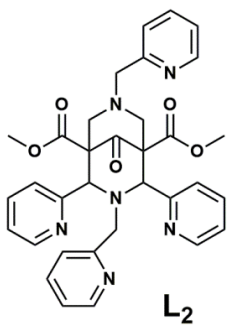

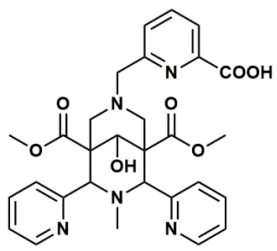

$\mathbf{L}_{7}$

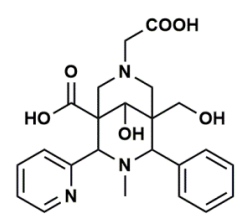

$\mathrm{L}_{12}$
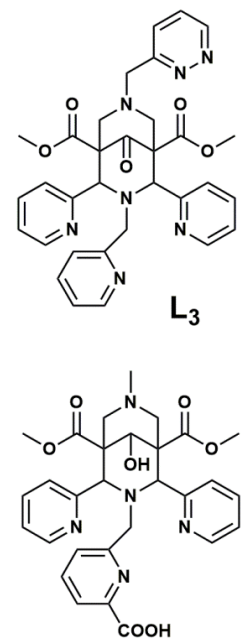

$\mathrm{L}_{8}$

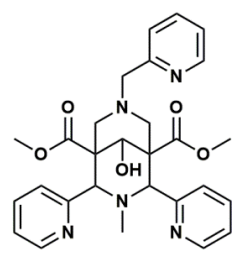

$\mathbf{L}_{13}$
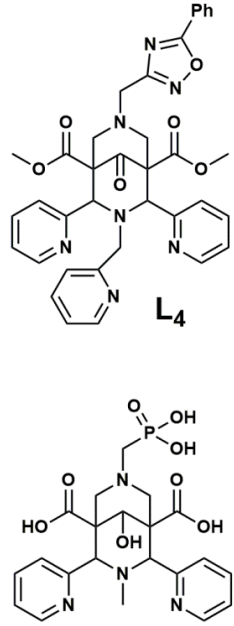

$L_{9}$

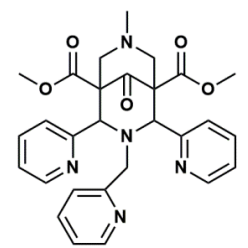

$\mathrm{L}_{14}$
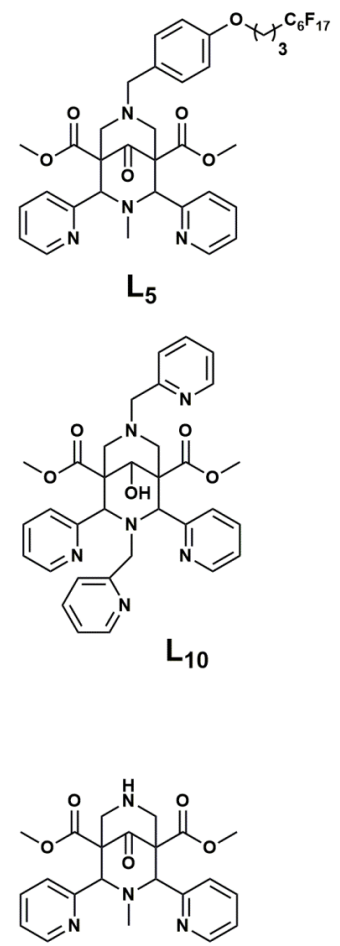

$\mathrm{L}_{15}$

Figure 5: Structures of reported 2,4-disubstituted bispidones and bispidines (corresponding references in brackets). 
rings are usually freely rotating and give averaged signals on the timescale of the NMR experiment. In other way, the splitting into two signals in NMR can be due to i) a cis-asymmetric conformation or ii) a trans configuration.

Whereas semiempirical ${ }^{17}$ and $\mathrm{DFT}^{9}$ calculations were performed in order to elucidate and anticipate the stereochemistry of the bispidones, the experimental yields of reactions do not always reflect the thermodynamic preference of one stereoisomer over the other possible conformations and configurations. Other aspects such as kinetic control, solid states interactions and/or solvent effects have to be taken into account in order to explain the crystallisation of the isolated isomer. In particular, energy minima of cis and trans configurations are in some cases very close $\left(\Delta \mathrm{G}^{\circ}\right.$ cistrans $=6.42 \mathrm{~kJ} \cdot \mathrm{mol}^{-1}$ for $\mathrm{L}_{2}: \mathrm{R}_{1}=\mathrm{CH}_{3}, \mathrm{R}_{2}=\mathrm{CH}_{2}$ py (Figure 5), $-0.9 \mathrm{~kJ} \cdot \mathrm{mol}^{-1}$ for $\mathrm{R}_{1}=\mathrm{CH}_{3}, \mathrm{R}_{2}=\mathrm{CH}_{2} \mathrm{CO}_{2} \mathrm{Et}$ and $2.2 \mathrm{~kJ}$.mol ${ }^{-1}$ for $\mathrm{R}_{1}=\mathrm{CH}_{2} \mathrm{CO}_{2} \mathrm{Et}, \mathrm{R}_{2}=\mathrm{CH}_{3}$ ) and trans to cis isomerisation (or vice versa) is possible upon heating. Such rearrangement has been evidenced on 3,7-dimethyl substituted bispidones with 2-pyridyl substituents at $\mathrm{C} 2$ and $\mathrm{C} 4,{ }^{35}$ as well as 3- and 4-nitrophenyl substituents, ${ }^{17}$ and in other cases. ${ }^{18}$ The rearrangement suggests a ring-opening by a retro-Michael mechanism followed by an inversion of the configuration of the carbon at the $\mathrm{C} 2$ (C4) position and is catalysed by the protonation of the keto group, which stabilizes the ring-opened form as an enol (Figure 6). According to experimental data, it seems that this reaction is under kinetic control of the formation of the open enol intermediate $I_{1}$. Such mechanism can be avoided by reduction of the ketone function at C9 (see § Reactivity and functionalisation).
Consequently, a new synthetic pathway has been developed in order to allow the introduction of sterically hindered and/or basic substituents at N3 and N7 in the cis-symmetrical chair-chair conformation (Figure 7). The first approach has been developed by Hasserodt and co-workers ${ }^{19}$ and is based on the introduction of a dimethoxybenzyl (DMB) protecting group at N7. This way allowed the authors to obtain three ligand variations, with a cis-symmetrical chair-chair configuration, in just one simple alkylation step. As examples, new ligands with pyridazine ( $L_{3}$, Figure 7$)$ or oxadiazole $\left(L_{4}\right.$, Figure 7$)$ coordinating moieties in $R_{2}$ position have been synthesized in three steps from the piperidinone intermediate. Lam et al. ${ }^{20}$ have also reported the alkylation in $\mathrm{R}_{2}$ position, using a chloro- or iodo-reactant in classical conditions $\left(\mathrm{Na}_{2} \mathrm{CO}_{3}, \mathrm{MeCN}\right)$. Very good alkylation yields (up to $85 \%$ ) have been reported. The obtained bispidone contains perfluorodecane moieties directly coupled on $R_{2}$ position with an ethyl or a O-benzyl spacer $\left(L_{5}\right.$ and $L_{6}$, Figure 7). More recently, Comba and co-workers ${ }^{21}$ have introduced a picolinate group in $R_{1}$ or $R_{2}$ positions ( $L_{7}$ and $L_{8}$, Figure 7 ).

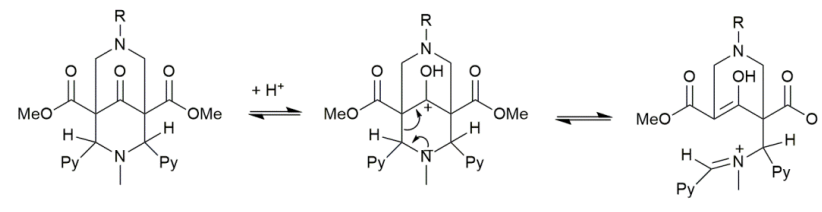

$I_{1}$

Figure 6: Trans/cis isomerisation mechanism. ${ }^{9}$<smiles>COC(=O)C12CN(Cc3ccc(OC)cc3OC)CC(C(=O)OC)(C1)[C@H](c1ccccn1)N(Cc1ccccn1)[C@@H]2c1ccccn1</smiles><smiles>COC(=O)C12CNCC(C(=O)OC)(C1)[C@H](c1ccccn1)N(Cc1ccccn1)[C@H]2c1ccccn1</smiles>

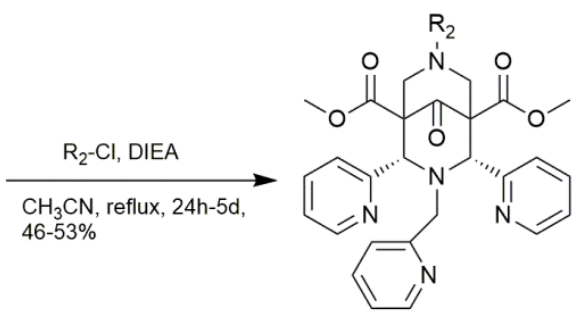

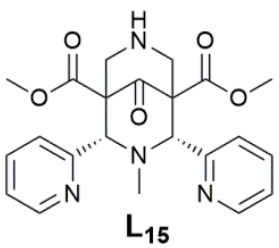
$\stackrel{\mathrm{R}_{2}-\mathrm{Cl} \text { or } \mathrm{R}_{2}^{\prime}-\mathrm{I}}{\mathrm{Na}_{2} \mathrm{CO}_{3}, \mathrm{CH}_{3} \mathrm{CN}}$
reflux, $24 \mathrm{~h}$

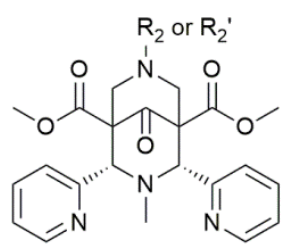

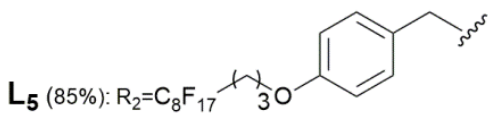

$$
\mathrm{L}_{5}(85 \%): \mathrm{R}_{2}=\mathrm{C}_{8} \mathrm{~F}_{17}+\underset{3}{\times}
$$

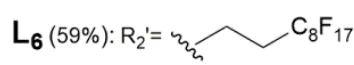<smiles>[R]N1CC2(C(=O)OC)CC(C(=O)OC)(C1)[C@H](c1ccccn1)N([R])[C@H]2c1ccccn1</smiles>

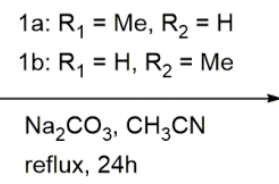

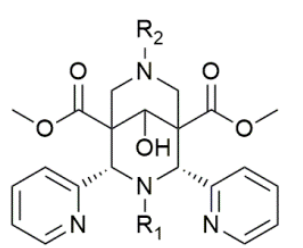<smiles></smiles>

Figure 7: Novel synthetic pathways for $\mathrm{N}$-alkylation (corresponding references in brackets). 
In this case, the central ketone has been reduced in order to increase the stability of the bispidine, especially during the alkylation step.

\section{Ditopic ligands}

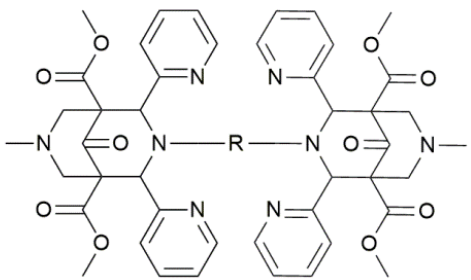

$R=$ ethylene $\left(L_{16}\right)$, propylene $\left(L_{17}\right)$, hexamethylene $\left(L_{18}\right)$, cyclohexane 1,4-bismethylene $\left(L_{19}\right)(24)$

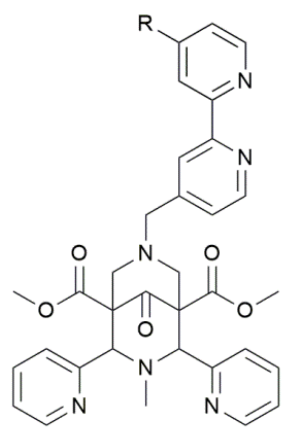

$L_{20}: R=H, L_{21}: R=C_{3}(25)$
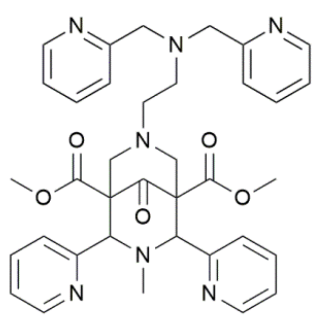

$\mathrm{L}_{22}(26)$

Figure 8: Ditopic ligands with variable length or different coordination sites.

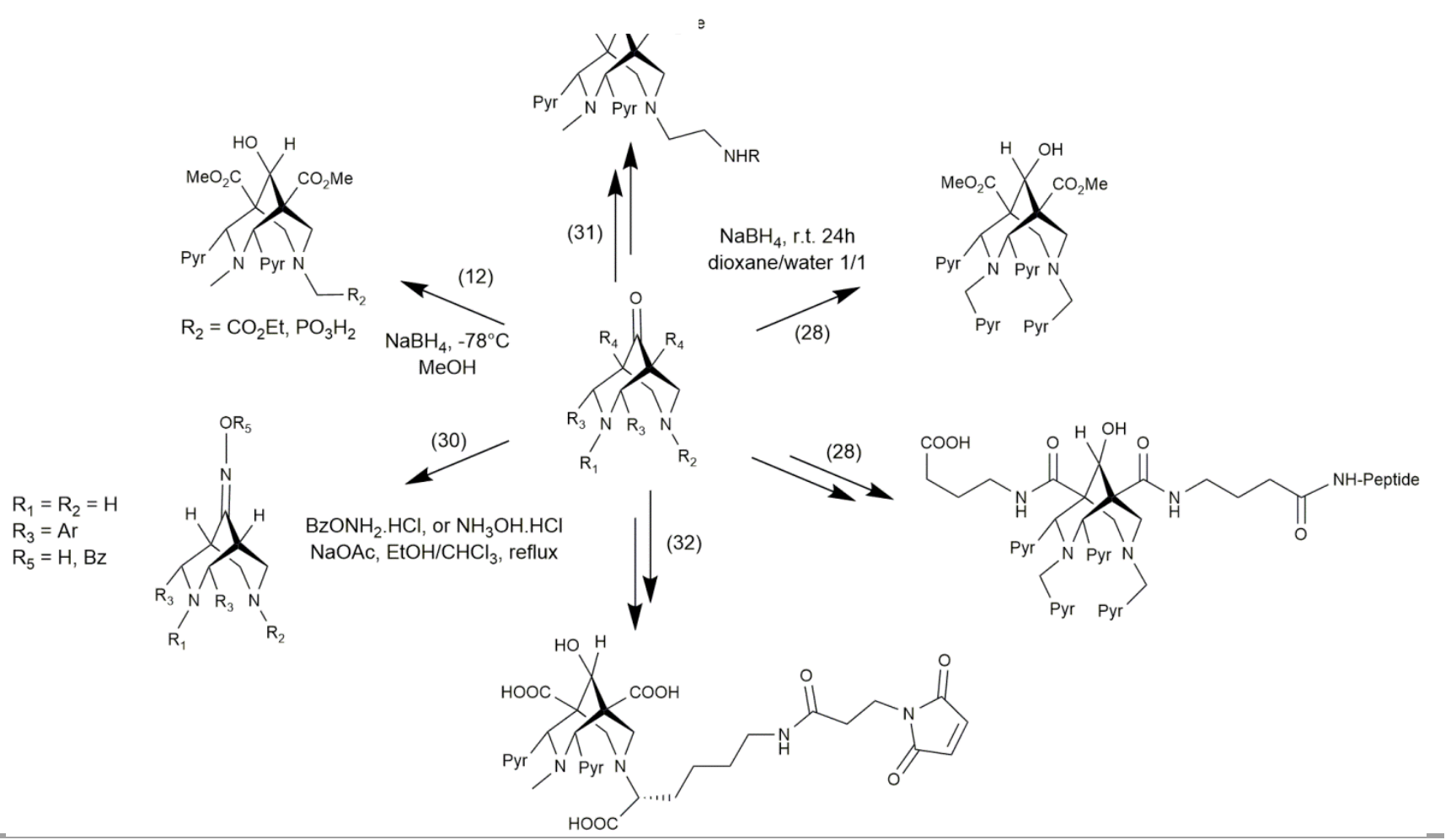

Figure 9. Various strategies for the functionalisation of bispidines (corresponding references in brackets).

As explained before, bispidine ligands have been used for their affinity to the $k$-opioid receptors and especially dimeric opioid ligands have been reported to have a high affinity and selectivity to many subtypes. ${ }^{22}$ For this purpose, new ditopic ligands have been obtained by varying the length of the spacer and the nitrogen substituents (Figure 8 ). ${ }^{23}$ Ligands $\mathrm{L}_{16}-\mathrm{L}_{19}$ were obtained in moderate yields ( 16 to $22 \%$ ) by a classical double-Mannich reaction. ${ }^{24}$ Later, asymmetric dinuclear ligands featuring two different binding pockets have also been obtained following the standard route: ligands $L_{20} L_{21}$ from 4-aminomethyl-2,2'-bipyridine (with $29 \%$ yield) and ligand $L_{22}$ from (bispyridinemethyl)ethanediamine. ${ }^{25,26}$ This latter compound was not isolated and instead complexation with $\mathrm{Cu}(\mathrm{II})$ and purification on a cation exchange column gave pure $\mathrm{CuL}_{22}$ complex.

\section{Reactivity and functionalisation}

Functionalisation of the backbone in other positions than $\mathrm{C} 2$ and $\mathrm{C} 4$ is interesting for a whole range of applications. Although the examples of functionalized bispidine or bispidone derivatives are still very scarce, these platforms offer a large panel of reactive sites, which can potentially be used for further conjugation. First, reduction of the carbonyl at $\mathrm{C} 9$ to an alcohol has been used since the mid 60 's, ${ }^{27}$ following the rate of acetylation of the corresponding alcohols being used for conformational analysis. Since then, facial diastereoselectivity of the ketone can be controlled in order to obtain only one diastereoisomer. Juran and co-workers ${ }^{28}$ reported the use of $\mathrm{NaBH}_{4}$ as reducing agent in an equivolumic mixture of water and dioxane, which afforded exclusively the anti epimer resulting from the addition of the hydride on the most hindered half of the starting bispidine (Figure 
9). It may be expected that intramolecular interactions occurred between $\mathrm{NaBH}_{4}$ and the pyridyl rings in positions 2 or 4 that direct the substitution on this side, resulting in the anti conformation, as evidenced by the X-ray crystal structure of the bispidol. Interestingly, the use of $\mathrm{MeOH}$ at low temperature instead of water at r.t. resulted in the opposite stereoselectivity with the formation of syn epimer, as reported by Roux and co-workers. ${ }^{12}$ The alcohol can also be further functionalized by formation of carbonates or carbamates as a versatile platform for subsequent reaction with amino derivatives, such a BODIPY dye, amino acids or peptides. ${ }^{29}$ Kabilan and his collaborators investigated the reactivity of the central ketone to form oximes and O-benzyloxime derivatives. ${ }^{30}$ It was shown that the formation of the oxime ethers does not affect the conformation of the bicyclic skeleton. This work holds promise for new (bio)conjugates since oxime bond formation can occur in mild conditions. Peptidic coupling provides bio-friendly conditions for biolabelling and has also been used on bispidol substituted with primary amine. The first example was reported by Stephan and Comba on the carboxylate substituents at $\mathrm{C} 1$ and $\mathrm{C} 5 .^{28}$ A bispidine-bombesine conjugate was obtained and used for ${ }^{64} \mathrm{Cu}$ PET imaging. This approach should be developed further as quantitative coupling is mandatory to avoid tremendous purification of the bioconjugates by HPLC. Very recently, new Cu(II) sensitive optical probes were obtained by Brox et al from a diethylamine-substituted bispidine at N7, followed by peptidic coupling with cyanine and rhodamine dyes (Figure 10). ${ }^{31}$ Finally, the use of aminoacids such as a $\mathrm{N}-\varepsilon$ protected lysine in the second step of the formation of the bispidine was used to develop functionalized bispidines and their coupled adducts. ${ }^{32}$

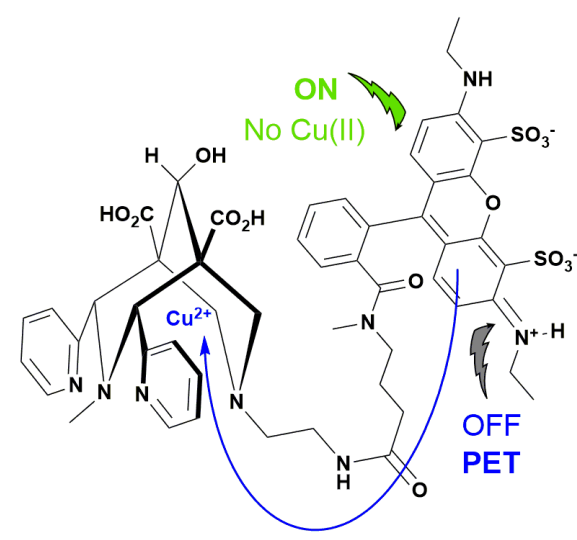

Figure 10: Bispidine-rhodamine conjugate used for $\mathrm{CU}(\mathrm{II})$ sensing: in presence of $\mathrm{Cu}(\mathrm{II})$, photoinduced electron transfer (PET) occurs and quenches the emission of the rhodamine dye. ${ }^{31}$

\section{Metal coordination chemistry}

\section{1. d-block Transition metals}

The coordination chemistry of bispidone with transition metal ions has been initiated by Haller in the $60^{\prime} \mathrm{s}^{33}$ At that time, Haller used IR spectroscopy to demonstrate the formation of coordination complexes between 2,4-disubstituted bispidone of the general formula such as represented in Figure 1 (with $\mathrm{R}=$ pyridyl, $\mathrm{R}^{\prime}=\mathrm{R}^{\prime \prime}=$ $\mathrm{CO}_{2} \mathrm{Me}$ or $\mathrm{CO}_{2} \mathrm{Et}, \mathrm{R}_{1}=\mathrm{H}$ and $\mathrm{R}_{2}=\mathrm{CH}_{3}$ or $\mathrm{CH}_{2}$ py) and divalent metal ions such as $\mathrm{Mn}, \mathrm{Fe}, \mathrm{Co}, \mathrm{Cd}$ and $\mathrm{Ni}$. Characteristic features are the $\mathrm{C}-\mathrm{H}$ bond vibrations that are observed at $2700-2800 \mathrm{~cm}^{-1}$ in the free bispidone with cis configuration and disappear upon metal coordination. These bands (also called Bohlmann bands) are due to the stretching of $\mathrm{C} 2 / 4-\mathrm{H}$ bonds that are anticoplanar with the N3 lone pair. $\mathrm{v}_{\mathrm{N}-\mathrm{H}}$ (at ca. $3200 \mathrm{~cm}^{-1}$ ) and $\mathrm{v}_{8 \mathrm{a}}$ of the pyridyl groups (around $1600 \mathrm{~cm}^{-1}$ ) are also affected. In this study, Haller enunciates the two prerequisites in terms of stereochemistry, for using bispidones as ligands for metal complexation:

- cis configuration of the pyridines substituents at C2 and C4

-chair/chair conformation of the 3,7-diazabicyclo[3.3.1]nonane scaffold (meaning that substituents at N3 and N7 are in equatorial position).

Solid-state structures of mononuclear complexes. Thirty years after the initial work of Haller, 2,4-substituted bispidone coordination chemistry was brought back to the forefront by Comba, who solved the crystal structure of the Co(II) complex of the tetradentate ligand $\mathrm{L}_{1}$. $\left[\mathrm{Co}\left(\mathrm{L}_{1}\right)\left(\mathrm{NO}_{3}\right)_{2}\right]$ displays a distorted octahedral geometry in which two nitrogens from the 3,7diazabicyclo[3.3.1]nonane ring (with a distance $d(\mathrm{Co}, \mathrm{N} 3 / 7)=$ 2.137(9) $\AA$ ) and two nitrogens from the pyridyl substituents at $\mathrm{C} 2 / 4$ are coordinated $(\mathrm{d}(\mathrm{Co}, \mathrm{Npy})=2.09(1) \AA)$, as well as a bidentate nitrate anion (Figure 11). ${ }^{33}$ This complex is characterised by short $\mathrm{N}$ Co distances in comparison to literature values for high spin octahedral $\mathrm{Co}$ (II) and by a strong rigidity of the bispidone backbone. Molecular mechanics was used to model various coordination geometries, therefore confirming the rigidity of the chair-chair bicycle (with a bite angle $\mathrm{N}(1)-\mathrm{M}-\mathrm{N}(2)$ of $85 \pm 2^{\circ}$ in all coordination geometries) and also predicting the possibility to accommodate other transition metal ions such as $\mathrm{Co}(\mathrm{III}), \mathrm{Cr}(\mathrm{III})$, low spin $\mathrm{Fe}(\mathrm{III})$ and $\mathrm{Cu}(\mathrm{II})$. Crystal structures have later been obtained with

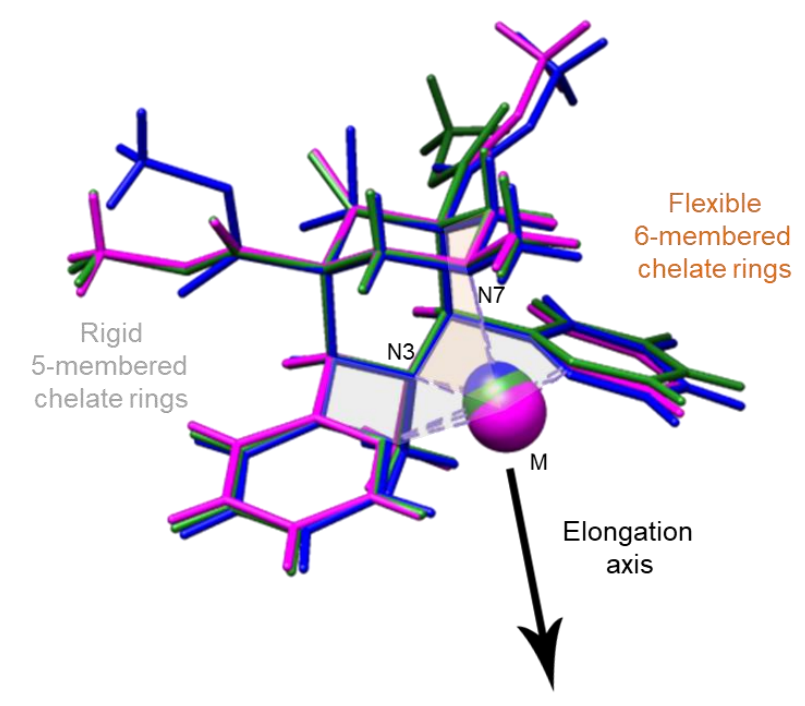

Figure 11: Superimposition of the $\mathrm{X}$-Ray structures of the complexes $\left[\mathrm{Co}\left(\mathrm{L}_{1}\right)\left(\mathrm{NO}_{3}\right)_{2}\right]^{33}$ (blue), $\left[\mathrm{Mn}\left(\mathrm{L}_{1}\right) \mathrm{Cl}_{2}\right]^{34}$ (magenta) and $\left[\mathrm{Fe}\left(\mathrm{L}_{1}\right)(\mathrm{NCS})_{2}\right]$ (green) ${ }^{35}$ showing that the position of the metal ion inside the cavity undergoes pseudo-Jahn-Teller elongation along the M-N7 axis. 


\begin{tabular}{lccccccccc}
\hline $\log K_{\mathrm{n}}{ }^{\mathrm{H}}$ & $\mathrm{L}_{13}(38)$ & $\mathrm{L}_{14}(38)$ & $\mathrm{L}_{2}(38)$ & $\mathrm{L}_{10}(38)$ & $\mathrm{L}_{7}(21)$ & $\mathrm{L}_{8}(21)$ & $\mathrm{L}_{11}(47)$ & $\mathrm{L}_{12}(12)$ & $\mathrm{L}_{9}(10)$ \\
\hline $\log K_{1}{ }^{\mathrm{H}}$ & $7.44(8)$ & $8.89(3)$ & $6.68(8)$ & $7.58(11)$ & $7.73(3)$ & $9.05(7)$ & $7.45(1)$ & $10.6(6)$ & $11.5(3)$ \\
$\log K_{2}{ }^{\mathrm{H}}$ & $3.95(10)$ & $5.21(4)$ & $4.72(1$ & $5.52(13)$ & $3.95(5)$ & $6.10(14)$ & $5.62(2)$ & $4.5(1)$ & $7.2(1)$ \\
$\log K_{3}{ }^{\mathrm{H}}$ & $1.86(10)$ & $2.50(4)$ & & & $1.82(12)$ & & $3.31(4)$ & $2.0(2$ & $3.8(3)$ \\
$\log K_{4}{ }^{\mathrm{H}}$ & & & & & & & & $0.82(1)$ & $2.4(4)$ \\
$\log K_{5}{ }^{\mathrm{H}}$ & & & & & & & & $<0.82$ & $0.5(1)$ \\
$\log K_{6}{ }^{\mathrm{H}}$ & & & & & & & & & $<0.5$ \\
\hline
\end{tabular}

$\mathrm{H}_{2} \mathrm{O}, \mathrm{I}=0.1 \mathrm{M}(\mathrm{KCl}), \mathrm{T}=25.0^{\circ} \mathrm{C}$. The numbers in parenthesis correspond to the standard deviations expressed as the last significant digit.

Table 1: Successive protonation constants reported for 2,4-substituted bispidones and bispidines (corresponding references in brackets).

$\left.\left[\mathrm{Mn}\left(\mathrm{L}_{1}\right) \mathrm{Cl}_{2}\right]\right)^{34}\left[\mathrm{Fe}\left(\mathrm{L}_{1}\right) \mathrm{X}_{2}\right](\mathrm{X}=\mathrm{OAc}, \mathrm{NCS}),^{35}\left[\mathrm{Ni}\left(\mathrm{L}_{1}\right)\left(\mathrm{H}_{2} \mathrm{O}\right) \mathrm{X}_{2}\right]\left(\mathrm{X}=\mathrm{NO}_{3}\right.$, $\left.\mathrm{PF}_{6}\right) .{ }^{36}$ This structure collection emphasizes the high similarity in all complexes, despite their varying coordination numbers and geometries (Figure 11). This is due to the strong rigidity of the

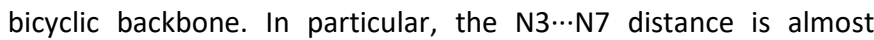
constant $(d(\mathrm{~N} 3, \mathrm{~N} 7)=2.533 \pm 0.025 \AA$ over 40 transition metal complexes with tetradentate derivatives of $\left.L_{1}\right)^{37}$ and rotation of the 2,4-substituents around the $\mathrm{C}-\mathrm{C}$ single bonds or of potential coordinating side-chains at N3 and N7 are the only degrees of freedom of these bispidine ligands. However, despite this strong rigidity, bispidine complexes display a flat potential energy surface which renders accessible a large number of coordination geometries (cis-octahedral, square pyramidal, pentagonal or even seven-coordinated) depending of the denticity of the ligand and/or of the number of co-ligands. ${ }^{5}$

Physico-chemical properties. The combination of a rigid ligand with an elastic coordination sphere has important repercussions on the thermodynamic stability, kinetic inertness, metal selectivity, redox properties and spin configuration of the mononuclear complexes $A$ very important fact is that the structure of the bispidine ligand intimately influences its function. In order to be able to correlate ligand/complex structures with their physico-chemical properties, individual properties of the ligands (such as protonation constants) and complexes (overall thermodynamic stability constants, redox potentials) have to be determined. Some details about the experimental determination of these parameters will be given in the two following sections as well as, for each parameter, a discussion on the structure/properties relationship.

Protonation constants, as defined by equations 1 and 2, are generally determined by potentiometric titrations (Table 1 ). ${ }^{38}$

$$
\begin{gathered}
\mathbf{L H}_{\mathrm{n}-1}+\mathbf{H} \leftrightarrow \mathbf{L H}_{\mathrm{n}} \\
K_{\mathrm{n}}^{\mathrm{H}}=\frac{\left[\mathrm{LH}_{\mathrm{n}}\right]}{\left.{ }_{\mathrm{LH}}\right][\mathrm{H}]} \\
\mathrm{p} K_{\mathrm{n}}{ }^{\mathrm{H}}=\log K_{\mathrm{n}}{ }^{\mathrm{H}}
\end{gathered}
$$

In the case of bispidine ligands substituted by aromatic groups at $\mathrm{C} 2$ and $\mathrm{C} 4$, protonation can also be monitored by UV-Visible absorption titrations. As an example, deprotonation of $L_{9}$ induces an hypochromic variation of the $\pi-\pi^{*}$ transition of the pyridine ring at ca. $260 \mathrm{~nm}\left(\varepsilon\left(\mathrm{L}_{9}{ }^{4-}\right)=16000 \mathrm{M}^{-1} \mathrm{~cm}^{-1}, \varepsilon\left(\mathrm{L}_{9} \mathrm{H}_{4}\right)=8000 \mathrm{M}^{-1} \mathrm{~cm}^{-1}\right.$, followed by the appearance of an hyperfine structure due to the participation of $\mathrm{N}$ lone pairs in hydrogen bonding (Figure 12). ${ }^{12}$

A comparison of literature data indicates that the first protonation occurs at the tertiary amines of the bispidine backbone in the $6.6 \leq$ $\mathrm{pK}_{\mathrm{a}}{ }^{1} \leq 11.5$ range (Table 1 ) and that the value of $\mathrm{pK}_{\mathrm{a}}{ }^{1}$ follows the increase of nucleophilicity of the nitrogen depending on the substituent, in the following order: picolinate < pyridinyl < methyl < glycinate $<$ methanephosphonate. Moreover, it is to be noted that the reduction of the ketone at C9 leads to a significant increase of the basicity of the amines N3 and N7 (see ligands $L_{2}$ and $L_{10}$ ). ${ }^{38}$ In addition, the protonation of the second tertiary nitrogen is not observed in the usual experimental conditions and it is surmised that 2,4-substituted bispidine behave as "proton sponges" in which the ammonium proton is stabilized inside the cavity by strong pseudo-hydrogen bonds with $\mathrm{N}_{3}, \mathrm{~N}_{7}$ and the pyridyl rings, resulting in a syn conformation. This is illustrated by the crystal structure of protonated ligands such as $L_{9}$ (Figure 12), ${ }^{10} L_{7}$ and $L_{8}{ }^{21}$ Finally, the relative position of the substituent at N3 or N7 has a strong influence on the $p K a$ as of the molecule, the proton inside the cavity being more stabilized when an additional coordinating group is introduced at N3 (Table 1).

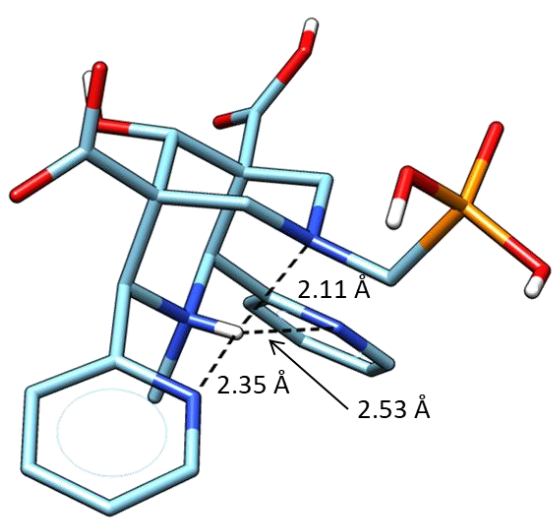

Figure 12: X-Ray structure of $\mathrm{H}_{4} \mathrm{~L}_{9}$ showing a proton sponge behaviour. ${ }^{10} \mathrm{C}-\mathrm{H}$ bonds are omitted for the sake of clarity. 


\begin{tabular}{|c|c|c|c|c|c|c|c|c|c|}
\hline & & $\mathrm{L}_{13}(38)$ & $\mathrm{L}_{14}(38)$ & $L_{2}(38)$ & $\mathrm{L}_{10}(38)$ & $L_{7}(21)$ & $L_{8}(21)$ & $\mathrm{L}_{12}(12)$ & $L_{9}(10)$ \\
\hline $\mathrm{Co}(\mathrm{II})$ & $\begin{array}{c}\text { ML } \\
M L H\end{array}$ & $6.23(5)^{\mathrm{a}}$ & $13.69(5)^{a}$ & $7.30(6)^{a}$ & $10.60(4)^{a}$ & & & $\begin{array}{c}11.1(2) \\
15.02(3)\end{array}$ & \\
\hline $\mathrm{Ni}(\mathrm{II})$ & $\begin{array}{c}\mathrm{ML} \\
\mathrm{MLH} \\
\mathrm{ML}(\mathrm{OH})\end{array}$ & $6.10(8)^{a}$ & $9.54(6)^{a}$ & $5.02(7)^{\mathrm{a}}$ & $7.20(10)^{a}$ & & & $\begin{array}{c}12.2(3) \\
16.7(2) \\
3.4(4)\end{array}$ & \\
\hline $\mathrm{Cu}(\mathrm{II})$ & $\begin{array}{c}\mathrm{ML} \\
\mathrm{MLH} \\
\mathrm{MLH}_{2}\end{array}$ & $18.31(2)^{a}$ & $15.66(3)^{\mathrm{a}}$ & $16.28(10)^{a}$ & & $\begin{array}{c}18.88(10) \\
21.07(6)\end{array}$ & $\begin{array}{c}19.44(18) \\
21.77(2)\end{array}$ & $19.2(3)$ & $\begin{array}{l}22.5(1) \\
27.4(3) \\
30.5(3)\end{array}$ \\
\hline $\mathrm{Zn}(\mathrm{II})$ & $\begin{array}{c}\mathrm{ML} \\
\mathrm{MLH} \\
\mathrm{MLH}_{2}\end{array}$ & $8.28(5)^{a}$ & $13.57(4)^{a}$ & $9.18(5)^{a}$ & $12.52(5)^{a}$ & & & $14.45(2)$ & $\begin{array}{l}18.8(1) \\
24.1(2) \\
27.2(2)\end{array}$ \\
\hline $\mathrm{Cu}(\mathrm{I})$ & & $5.69(22)^{\mathrm{b}}$ & $6.29(43)^{b}$ & $4.97(52)^{\mathrm{b}}$ & & & & & \\
\hline $\mathrm{pCu}(\mathrm{II})^{\mathrm{c}}$ & & & & 16.28 & & 19.3 & 18.7 & 17.0 & 19.1 \\
\hline $\begin{array}{c}\mathrm{E}_{\mathrm{red}}\left(\mathrm{Cu}^{\mathrm{II} / 1}\right) \\
(\mathrm{mV})\end{array}$ & & -324 & -214 & -303 & -234 & $\begin{array}{l}-1002 * \\
\quad * v f c\end{array}$ & $\begin{array}{l}-1170 * \\
n D M F\end{array}$ & -560 & -600 \\
\hline
\end{tabular}

${ }^{\mathrm{a}} \mathrm{H}_{2} \mathrm{O}, \mathrm{I}=0.1 \mathrm{M}(\mathrm{KCl}), \mathrm{T}=25.0^{\circ} \mathrm{C} .{ }^{b} \mathrm{CD}_{3} \mathrm{CN}, \mathrm{I}=0.1 \mathrm{M}(\mathrm{KCl}), \mathrm{T}=25.0^{\circ} \mathrm{C} .{ }^{\mathrm{c}} \mathrm{pM}=-\log \left[\mathrm{M}_{\text {free }}\right]$ with $[\mathrm{M}]=10^{-6} \mathrm{M}$ and $[\mathrm{L}]=10^{-5} \mathrm{M}, \mathrm{pH}=7.4$.

The numbers in parenthesis correspond to the standard deviations expressed at the last significant digit.

Table 2: Overall stability constants $(\log \beta)$ of the $\mathrm{MLH}_{\mathrm{n}}$ species and reduction potential $\left(\mathrm{E}_{\mathrm{red}}\left(\mathrm{Cu}^{\mathrm{II} / 1}\right)\right.$ in $\mathrm{H}_{2} \mathrm{O}$ vs $\left.\mathrm{NHE}\right)$ of various transition complexes with 2,4-pyridyl bispidines (corresponding references in brackets).

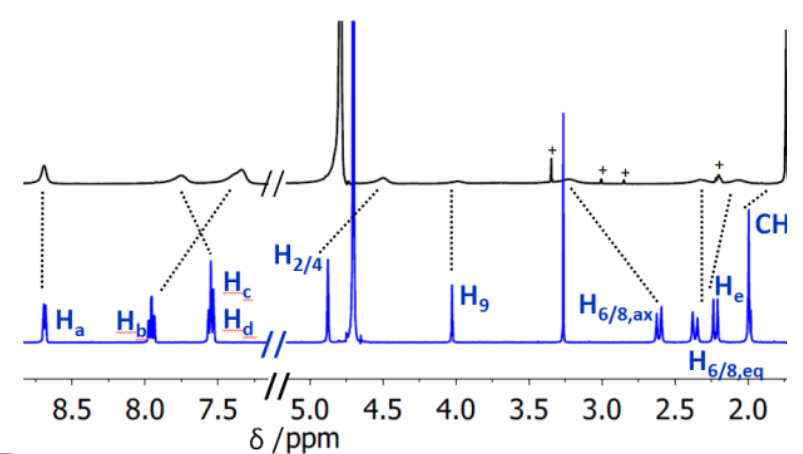

Figure 13: ${ }^{1} \mathrm{H}$ NMR spectra $\left(\mathrm{D}_{2} \mathrm{O}, 400 \mathrm{MHz}\right)$ of $\mathrm{L}\left(\mathrm{PO}_{3} \mathrm{H}_{2}\right)$ at $\mathrm{pD}=12.25$ (top) and $\mathrm{ZnL}_{9}$ at $\mathrm{pD}=12.6$ (bottom). ${ }^{10}$

Metal complexation of the bispidines can be qualitatively studied by ${ }^{1} \mathrm{H}$ NMR in presence of a 1:1 stoichiometric mixture of ligand and diamagnetic metal ion such as $\mathrm{Zn}(\mathrm{II}), \mathrm{Ga}(\mathrm{III})^{39}$ or $\mathrm{Cu}(\mathrm{I}) .^{38}$ Whereas ligands with boat-chair conformation and trans configuration give rise to complex mixtures of species, chair-chair conformers with cis configuration such as $\mathrm{L}_{10}, \mathrm{~L}_{12}{ }^{12}$ and $\mathrm{L}_{9}{ }^{10}$ give only one set of protons. As an example, the ${ }^{1} \mathrm{H}$ NMR spectra of $\mathrm{L}_{9}$ in presence of $\mathrm{ZnCl}_{2}$ is depicted in Figure 13.

In basic conditions ( $\mathrm{pD}>12$ ), one set of resolved peaks is observed for the $\mathrm{Zn}$ (II) complex whereas broad signals are observed for the ligand due to the equilibrium between $\mathrm{L}^{4-}$ and $\mathrm{LH}^{3-}$ species $\left(\mathrm{L}=\mathrm{L}_{9}\right)$. Strong variations are also noticed on the phosphorus atom by ${ }^{31} \mathrm{P}$ NMR. Monitoring these variations as a function of $\mathrm{pH}$ (Figure 14) indicates that the first protonation of the $\mathrm{ZnL}_{9}$ complex occurs on the phosphonate function, with a protonation constant of $\mathrm{pKa}_{1}=5.4(1)$. A second protonation step is also observed below $\mathrm{pH}$ 4 , which could be assigned to the protonation of the carboxylate function. ${ }^{10}$

Overall thermodynamic stability constants of bispidine complexes with $M(I I)$ ions $\left(\beta_{\mathrm{MLH}_{n}}\right)$, as defined by equations 4 and 5 , are
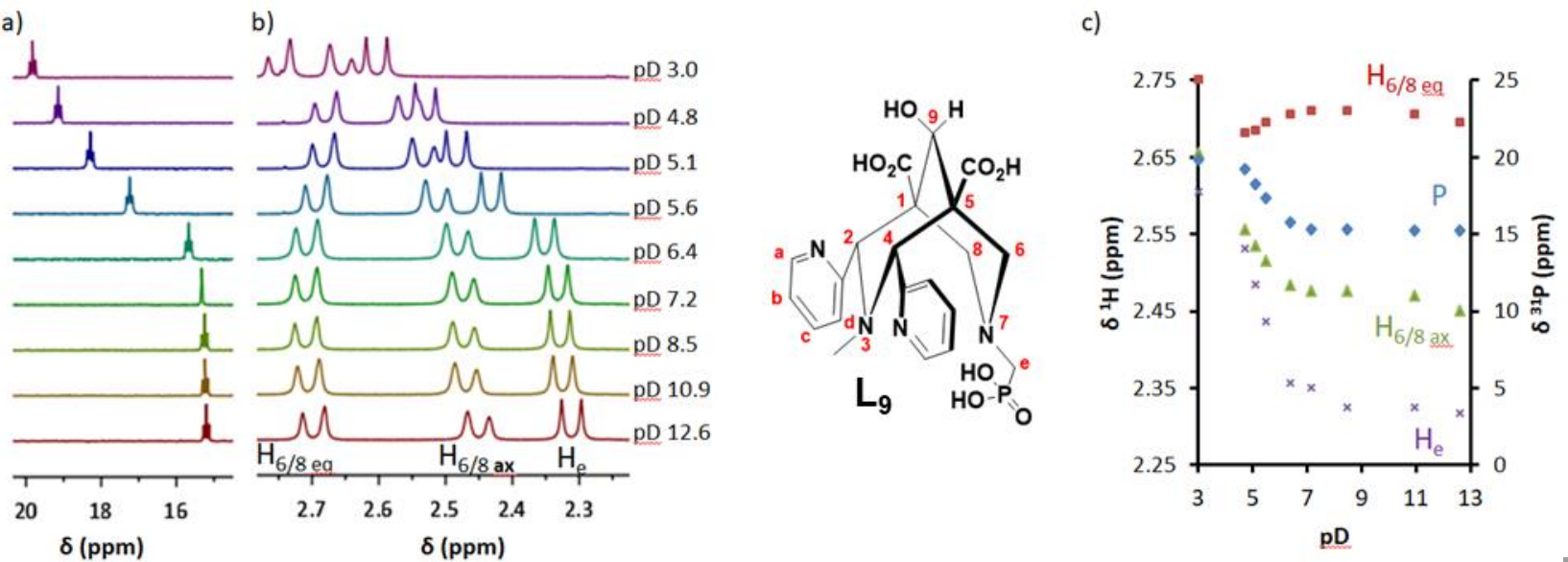

Figure 14: (a) ${ }^{31} \mathrm{P}$ NMR spectra (162 MHz), (b) Zoom of the ${ }^{1} \mathrm{H}$ NMR spectra (400 MHz) in the 2.25-2.75 region of a 1:1: $\mathrm{L}_{9}: \mathrm{ZnCl}_{2}$ solution in $\mathrm{D}_{2} \mathrm{O}$ at $25^{\circ} \mathrm{C}$. and c) protonation curves $\delta=f(p D) .^{10}$

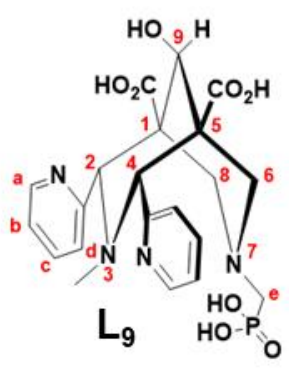


generally determined by potentiometric titrations together with, in some cases, UV/visible spectrophotometric titration versus $\mathrm{pH}$.

$$
\begin{gathered}
\mathbf{L H}_{\mathbf{n}}+\mathbf{M} \leftrightarrow \mathbf{M L H}_{\mathbf{n}} \\
\beta_{\mathrm{MLH}_{n}}=\frac{\left[\mathrm{MLH}_{n}\right]}{\left[\mathrm{LH}_{\mathrm{n}}\right][\mathrm{M}]}
\end{gathered}
$$

The obtained values are summarized in Table 2 . In the case of ligands $L_{7}, L_{8}, L_{9}$ and $L_{12}$, direct potentiometric titrations do not allow the determination of the formation constant with $\mathrm{Cu}$ (II) since more than $95 \%$ of the metal ion is already complexed at pH 2 (as $\mathrm{CuLH}$ and $\mathrm{CuLH}_{2}$ species). The constants have therefore been obtained by competition with ethylenediaminetetraacetic acid (EDTA) by monitoring $\mathrm{pH}=\mathrm{f}\left(\mathrm{n}_{\mathrm{OH}}\right)$ of $\mathrm{Cu}(\mathrm{II}) / \mathrm{L} /$ EDTA mixtures in a 1:1:1 ratio $\left(L=L_{7}\right.$ or $\left.L_{8}\right){ }^{39}$ In the case of $L_{12}$ and $L_{9}$, batch $U V$-visible titrations have been performed in the $\mathrm{pH}$ range $-0.6 \leq \mathrm{pH} \leq 12$, while looking at the $\pi-\pi^{*}$ transitions of the pyridyl rings (at $260 \mathrm{~nm}$ ) and at the $\mathrm{Cu}(\mathrm{II}) d-d$ transitions centred around $700 \mathrm{~nm}$. In such experiment, the position of the absorption maximum of $d$ - $d$ transitions provides information about the geometry of the coordination sphere, i.e. square pyramidal in the case of $L_{9}$.

When looking at the stability constants of $\mathrm{Zn}(\mathrm{II}), \mathrm{Co}(\mathrm{II})$ and $\mathrm{Ni}(\mathrm{II})$ complexes, it appears that the values rarely fits the Irwing-Williams series and for a majority of bispidine ligands, the trend $\mathrm{Cu}>\mathrm{Zn}>\mathrm{Co}>>\mathrm{Ni}$ is observed, which can be related to electronic (Jahn-Teller) effects (see below). The good selectivity for $\mathrm{Cu}(\mathrm{II})$ over $\mathrm{Zn}(\mathrm{II}), \mathrm{Co}(\mathrm{II})$ and more especially $\mathrm{Ni}(\mathrm{II})$, has prompted the development of bispidine-based ${ }^{64} \mathrm{Cu}(\mathrm{II})$ radiotracers. ${ }^{11}$ Moreover, bispidine-dye conjugates with green rhodamine and red cyanine fluorescent tags have also been developed in order to achieve $\mathrm{Cu}$ (II) fluorescent sensing. ${ }^{31}$ In such systems, whereas the fluorescence of the dyes is almost not affected by other metal ions such as Co(II), $\mathrm{Ni}(\mathrm{II}), \mathrm{Fe}(\mathrm{II}), \mathrm{Mg}(\mathrm{II})$ and $\mathrm{Ca}(\mathrm{II})$, photoinduced electron transfer occurs in the excited states of the $\mathrm{Cu}$ (II) complex to form a nonluminescent $\mathrm{Cu}(\mathrm{I})$-oxidised dye conjugate (Figure 10). Several examples of bispidine complexes with $\mathrm{Cu}(\mathrm{I})$ (with ligands $\mathrm{L}_{13}, \mathrm{~L}_{14}$ and $\mathrm{L}_{2}^{38}$ ) have been studied in details in non-aqueous media under argon atmosphere in order to prevent oxidation to $\mathrm{Cu}(\mathrm{II})$. The thermodynamic stability constants of corresponding $\mathrm{Cu}(\mathrm{I})$ complexes are summarized in Table 2.

An interesting property of bispidine coordination complexes is that, due to the high complementarity for $\mathrm{Cu}(\mathrm{II}), \mathrm{Cu}(\mathrm{II}) \leftrightharpoons \mathrm{Cu}(\mathrm{I})$ reduction and oxidation processes are usually quasi-reversible, with low reduction potentials (Table 2 ). In neutral $\mathrm{pH}$ conditions, no demetallation is observed at low reduction potential, in agreement with the stabilisation of both $\mathrm{Cu}(\mathrm{I})$ and $\mathrm{Cu}(\mathrm{II})$ complexes. Moreover, reduction potentials can be tuned by varying the substituents at N3 and N7, as they are linearly correlated to the relative stability of the $\mathrm{Cu}(\mathrm{I})$ and $\mathrm{Cu}(\mathrm{II})$ species. $^{11}$ In particular, for neutral tetradentate bispidine ligands with constant and rigid ligand structure, redox potentials are mostly dependant on electrostatic interactions and can therefore be estimated from the value of the $\mathrm{p} K_{\mathrm{a}}$ of the pyridine rings, substituted or not. ${ }^{14}$ It has to be noted that, negatively charged ligands with methylpicolinate, ${ }^{39}$ methylcarboxylate or methylphosphonate substituents induce a stabilisation of both $\mathrm{Cu}(\mathrm{II})$ and $\mathrm{Cu}(\mathrm{I})$ complexes.
Electronic and magnetic properties. The last feature of bispidine complexes is their Jahn-Teller lability. Although the ligand backbone is very rigid, it appears that the position of the metal ion in the ligand cavity is not fixed and depends on the nature of the metal ion and of the ligands, resulting in an adaptable coordination sphere (Figure 11). Two families of structures can be distinguished when looking at the position of the metal ion inside the ligand cavity: one with M-N3 < M-N7 and the other with M-N3 $\geq$ M-N7. Flexibility arises from the M-N7 bond, which is part of 6-membered chelate rings while the $\mathrm{M}-\mathrm{N} 3$ bond is part of two rigid 5-membered chelate rings (Figure 11). Tetragonal $\mathrm{Cu}(\mathrm{II})$ complexes with tetradentate bispidine ligands (square-pyramidal or distorted octahedral geometry) are usually characterized by a pseudo-JahnTeller elongation on the Cu-N7 axis. While comparing crystal structures of $\mathrm{Cu}\left(\mathrm{L}_{1}\right)$ complexes and derivatives with parasubstituents $\left(p \mathrm{NO}_{2}, p \mathrm{Cl}, p \mathrm{Br}, p \mathrm{Me}, \ldots.\right)$ on the pyridine $\mathrm{R}$-groups in presence of various co-ligands, important variations are observed on the Cu-N7 bond length (0.12 $\AA$ magnitude), whereas Cu-N3 bonds remain almost constants $(\leq 0.041 \AA) .{ }^{14}$ The elongation of the Cu-N7 axis can also be monitored in solution by recording the absorption spectra of the $d$-d transitions. ${ }^{14}$ Whereas the $d_{x y} \rightarrow d_{x 2-y 2}$ transition (at ca. $630 \mathrm{~nm}$ ) is not significantly affected by the Cu-N7 distance, $d_{z^{2}} \rightarrow d_{x 2-y 2}$ strongly depends on coordination parameters and can fluctuate from $850 \mathrm{~nm}$ to $1000 \mathrm{~nm}$. The elongation is favourable to $\mathrm{Cu}(\mathrm{II}), \mathrm{Ni}(\mathrm{II}), \mathrm{Zn}(\mathrm{II})$ and $\mathrm{Ga}(\mathrm{III})$, the difference between the distances $d(\mathrm{M}, \mathrm{N} 3)$ and $d(\mathrm{M}-\mathrm{N} 7)$ being more important for $\mathrm{Cu}(\mathrm{II})$ complexes. However, such elongation is not favourable to $\mathrm{Co}(\mathrm{II})^{39}$ thereby leading to deviation to the expected Irving-Williams trend.

Noteworthy, replacement of the pyridyl groups at C2 and C4 by bulkier substituents such as $\alpha$-methylated pyridines or quinolines give rise to three types of Jahn-Teller isomers along the N7-Ar, Ar1$\mathrm{Ar} 2$ and N3-Ar, respectively, depending on the co-ligand $\left(\mathrm{Cl}^{-}, \mathrm{OH}_{2}\right.$, $\mathrm{NCCH}_{3}$, or $\left.\mathrm{ONO}^{2-}\right) .^{40}$ As an example for a pentadentate ligand, $\mathrm{L}_{14}$ gives rise to elongations along the N7...py3 axis (where py $3=\mathrm{R} 1$ ) or

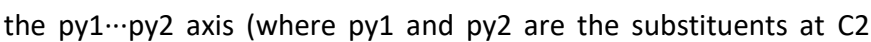
and $\mathrm{C} 4$ ). In the case of hexadentate ligands such as $\mathrm{L}_{2}{ }^{18}$ elongation occurs along the py $1 \cdots$ py 2 axis. However, this is not the case when more flexible pendant arms are introduced on N3 and N7.

These elongations are often called pseudo-Jahn-Teller elongations because they induce a distortion of the ligand field and therefore they remove the electronic degeneracy of the $5 d$ orbitals. This effect is particularly strong for $d^{9}$ metal complexes such as $\mathrm{Cu}$ (II) however it is also very interesting for $d^{5}$ and $d^{4}$ ions such as $\mathrm{Fe}(\mathrm{III} / \mathrm{IV})$ and $\mathrm{Ru}(\mathrm{III})$ for which it can be used to stabilize a single spin state, either low-spin or high-spin. Comba and Que demonstrated that spin conversion was possible by changing the co-ligands of a bispidine complex. The first evidence of a spin-crossover behaviour (SCO) of such complexes was observed on an alkylperoxo Fe(III) complex with the ligand $\mathrm{L}_{1}{ }^{41}$ The meta-stable intermediate can be obtained by oxidation of $\left[\mathrm{Fe}\left(\mathrm{L}_{1}\right)\left(\mathrm{X}_{2}\right)\right]^{2+}\left(\mathrm{X}=\mathrm{OH}_{2}, \mathrm{OH}^{-}\right.$or $\left.\mathrm{NCCH}_{3}\right)$ with 2 equivalents of $\mathrm{tBuOOH}$ in acetonitrile at $-40^{\circ} \mathrm{C}$. The obtained species are characterised by two sets of signals in EPR (4K) in $\mathrm{CH}_{3} \mathrm{CN}$, which were assigned to the low-spin $\left(g_{\mathrm{ls}}=1.97,2.13,2.16\right)$ and to the 
high-spin $\left(g_{\mathrm{hs}}=4.3\right)$ states, respectively. Replacing $\mathrm{CH}_{3} \mathrm{CN}$ by noncoordinating $\mathrm{CH}_{2} \mathrm{Cl}_{2}$ increases the proportion of the high-spin states (Figure 15). These observations can be correlated with changes in the resonance Raman spectra. In particular, noticeable differences are observed in the $\mathrm{Fe}-\mathrm{O}$ and $\mathrm{O}-\mathrm{O}$ bond strengths, resulting in different reactivity: the high-spin intermediate displays a weaker Fe-O bond $\left(v_{\mathrm{Fe}-\mathrm{O}, \mathrm{hs}}=652 \mathrm{~cm}^{-1}, v_{\mathrm{Fe}-\mathrm{O}, \mathrm{ls}}=694 \mathrm{~cm}^{-1}\right)$ and undergoes a FeOOR bond cleavage whereas the low-spin species is characterised by an activated FeO-OR bond $\left(v_{0-0,1 s}=790 \mathrm{~cm}^{-1}, v_{\mathrm{O}-0, \mathrm{hs}}=875 \mathrm{~cm}^{-1}\right)$ and as a consequence, can form $\mathrm{Fe}(\mathrm{IV})=\mathrm{O}$ and $\mathrm{RO}^{\circ}$ reactive species. ${ }^{41}$ Replacing $\mathrm{CH}_{3} \mathrm{CN}$ by a pyridine- $\mathrm{N}$-oxide co-ligand, give rise to an unique high-spin species.

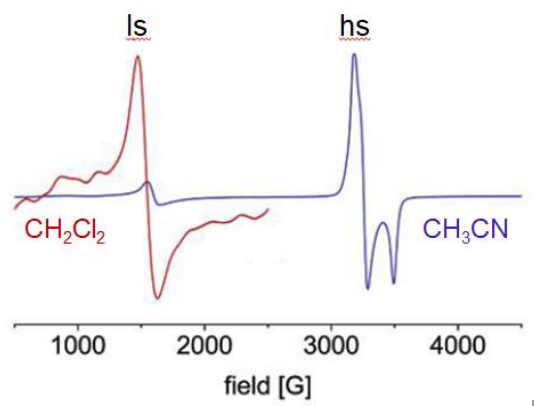

Figure 15: Comparison of the $\mathrm{X}$-band EPR spectra (4K) of $\left[\mathrm{Fe}\left(\mathrm{L}_{1}\right)(\mathrm{OOtBu})(\mathrm{X})\right]^{2+}$ in $\mathrm{CH}_{3} \mathrm{CN}\left(\mathrm{X}=\mathrm{OH}_{2}, \mathrm{OH}^{-}\right.$or $\left.\mathrm{NCCH}_{3}\right)$ and $\mathrm{CH}_{2} \mathrm{Cl}_{2}$. Adapted with permission from ref 41. Copyright 2019 American Chemical Society.

The role of the co-ligand is described in reference ${ }^{42}$ with the study of bispidone iron(IV) oxo complexes with pentadentate ligands $L_{14}$ and $L_{2}$. In summary, the addition of a sixth ligand reduces the relative stability of the high-spin states with the order $\mathrm{OH}-<\mathrm{OH}_{2}(\pi-$ donors) $\ll \mathrm{NCCH}_{3}<$ pyridine ( $\pi$-acceptors), due to the ligand field strengths. In addition, the sixth ligand defines the orientation of the Jahn-Teller axis (along N7-Fe-X or $\mathrm{N}_{\text {pyr }}-\mathrm{Fe}-\mathrm{N}_{\text {pyr }}$ ). In a similar manner, temperature changes on the magnetic moment of the intermediate $\mathrm{L}_{15}$ have been observed by Hasserodt and coworkers, which were assigned to an exchange of monodentate acetonitrile in the sixth position with bulk water. ${ }^{19}$ Based on these observations, a true SCO behaviour in water was obtained with the hexacoordinated complex $\left[\mathrm{FeL}_{2}\right]$ for which low-spin iron centres $(\mu=1.31-2.96 \mathrm{BM}$ at $20-80^{\circ} \mathrm{C}$ ) are converted to high spin upon heating, the entire population being converted at $80^{\circ} \mathrm{C}$ (Figure 16). ${ }^{19}$ However, no temperature changes are observed in $\mathrm{CD}_{3} \mathrm{CN}$ and a contribution of coordination-decoordination equilibrium (Figure 16) cannot be ruled out.

Stabilisation of the hexacoordinated complex and therefore increase of the ligand field strength has been achieved by replacing the methylpyridyl substituent at N7 by pyridazinylmethyl $\left(L_{3}\right)$ and oxadiazolylmethyl $\left(L_{4}\right)$ substituents (see Figures 5 for the structures of the ligands), which are less sterically hindered because of the absence of substituent in the $\alpha$ position of the coordinated nitrogen. Suppression of the steric clash gave birth to the first lowspin iron(II) complexes with bispidine ligands. ${ }^{19}$ Interestingly, these low-spin complexes are characterized by a radial compression (with $d(\mathrm{Fe}, \mathrm{N})$ of ca. $2.0 \AA$ ) whereas all coordination bond lengths are approximately $2.2 \AA$ in the high-spin bispidine complexes. When a bis-2-methylpyridyl unit is present at N7, high-spin Fe(II) complexes are obtained, with partial coordination of the pendant arm. ${ }^{43}$ The same ligand gave heptacoordinated $\mathrm{Mn}$ (II) complexes with a distorted pentagonal bispyramidal coordination sphere filled by 6 nitrogen atoms from the bispidine and an additional $\mathrm{Cl}^{-}$ligand. This important distorsion in the pentagonal plane led to long $\mathrm{Mn}-\mathrm{N}$ distances and a stable high-spin state.

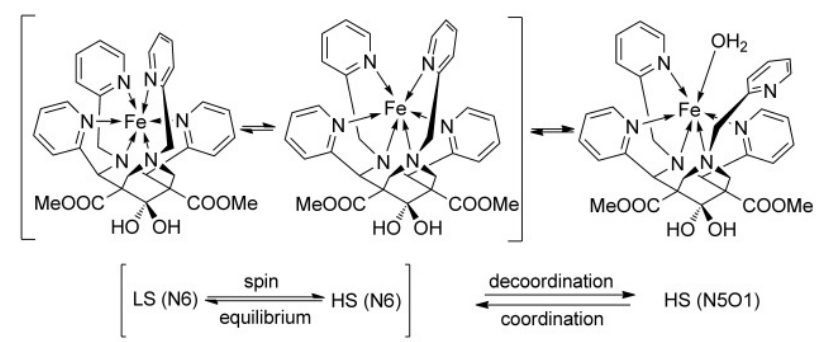

Figure 16: Possible spin equilibria for $\left[\mathrm{FeL}_{2}\right]$ in water solution. LS=low spin, HS=high spin. Adapted with permission from ref 19. Copyright 4583000081286 Chemistry - A European Journal.

Finally, application to single-molecule magnets (SMMs) has also been envisaged. A SMM is a molecular magnet that exhibit magnetization hysteresis below a certain blocking temperature. Above this temperature relaxation of the magnetization becomes fast. Heteronuclear triads have been synthesized in which hexacyanometalates $\mathrm{K}_{3}\left[\mathrm{M}(\mathrm{CN})_{6}\right] \quad(\mathrm{M}=\mathrm{Cr}(\mathrm{III}), \mathrm{Fe}(\mathrm{III}))$ are being sandwiched between two bispidine complexes with $\mathrm{Mn}(\mathrm{II}), \mathrm{Ni}(\mathrm{II})$ or $\mathrm{Cu}(\mathrm{II}){ }^{44}$ In these examples, cyanometalates were expected to induce a large negative axial magnetic anisotropy (due to the strong ligand field of $\mathrm{CN}^{-}$) and to compensate for the relatively small values of the total spin. $\mathrm{K}_{3}\left[\mathrm{Co}(\mathrm{CN})_{6}\right]$ has also been used as a diamagnetic reference for which no magnetic coupling has been observed. Bispidine ligands $L_{13}$ and its analogue with quinolyl substituents at C2 and C4 have been used, resulting in the formation of heteronuclear triads with two different configurations and intermetallic distances of $c a .5 \AA$ : a linear isomer in which the hexacyanometalate centre displays a trans configuration (with $\mathrm{L}_{13}$ ) and a bent isomer (with quinolyl) in which the central hexacyanometalate unit is in the cis configuration (Figure 17). The selectivity is probably due to a combination of Van der Waals repulsion and $\pi$-stacking effects. Ferromagnetic coupling between $\mathrm{Fe}(\mathrm{III})-\mathrm{Cu}(\mathrm{II})$ and $\mathrm{Fe}(\mathrm{III})-\mathrm{Mn}$ (II) has been observed and antiferromagnetic coupling for $\mathrm{Cr}$ (III)-Mn(II) triads but with no SMM behaviour. This was attributed to the large angular distortion of the $\left[\mathrm{M}(\mathrm{CN})_{6}\right]^{3-}$ unit. $^{45}$ 
Complexes with ditopic ligands. Tetrametallic systems with ditopic ligands such as those depicted on Figure 8 have shown interest for the activation of molecular dioxygen. $\left[\mathrm{Cu}_{4} \mathrm{~L}_{22} \mathrm{Cl}_{4}\right]\left(\mathrm{ClO}_{4}\right)_{4} \cdot 2 \mathrm{H}_{2} \mathrm{O}$ tetrades have also been obtained (Figure 18), in which the incorporation of a (bispyridinemethyl)ethanediamine substituent (see Figure 8 for the drawing of the ligand) allows the complexation of two equivalent $\mathrm{Cu}(\mathrm{II})$ atoms with a octahedral geometry (Cu1) and of two other $\mathrm{Cu}(\mathrm{II})$ centres in the bispidine cage (Cu2). ${ }^{26}$ Weak antiferromagnetic coupling is observed between Cu1 and Cu2 centres of a ditopic ligand $(d(\mathrm{Cu} 1, \mathrm{Cu} 2)=4.79 \AA$, Figure 18) whereas strong ferromagnetic coupling occurs between the two Cu1 centres in the square-planar bis-chloride bridge $\left(d\left(\mathrm{Cu} 1, \mathrm{Cu} 1^{\mathrm{i}}\right)=3.49 \AA\right)$.

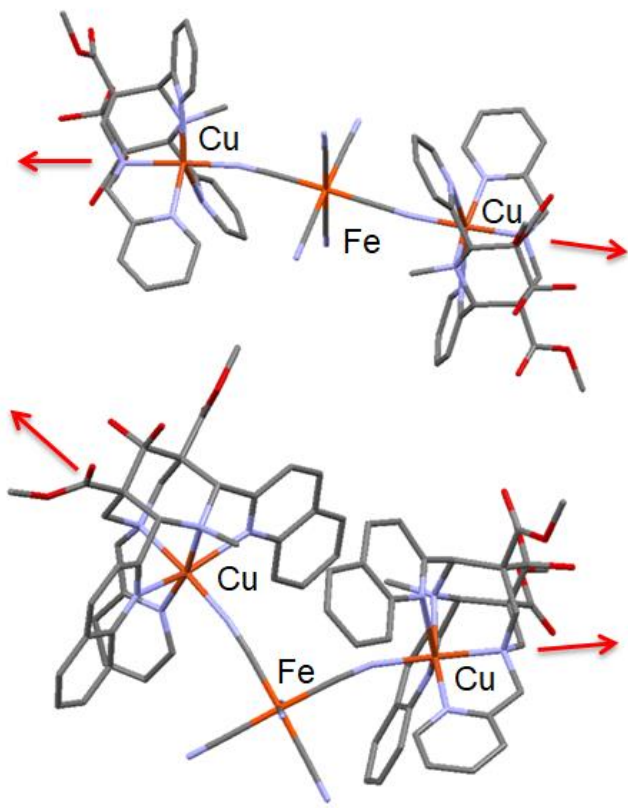

Figure 17: X-ray structures of $\mathrm{Fe}(\mathrm{III})-\mathrm{Cu}(\mathrm{II})$ triads with ligand $\mathrm{L}_{2}$ (top) and the quinolyl derivative (bottom) and elongation of the Jahn-Teller axis $(\rightarrow) .^{45}$

\section{Indium, lanthanides and actinides}

With the aim to develop theranostic agents combining Single Photon Emission Computed Tomography imaging (SPECT) and Auger radiotherapy, new bispidine-type ligands are being developed for the complexation of ${ }^{177} \mathrm{Lu},{ }^{111} \mathrm{In}$ and ${ }^{225} \mathrm{Ac}(\mathrm{III})$. The

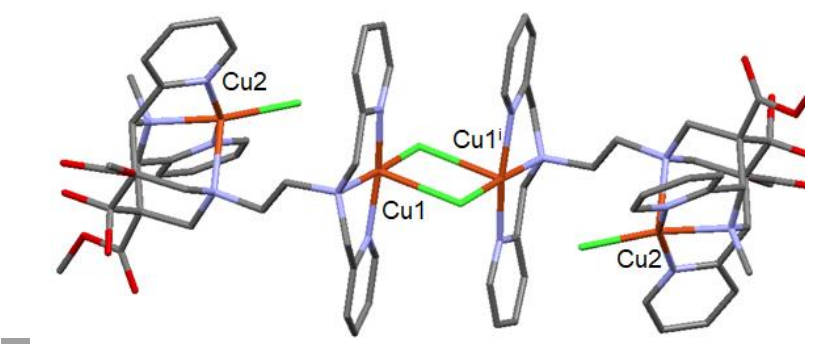

Figure 18: $X$-ray structure of a centrosymmetric $\left[\mathrm{Cu}_{4} \mathrm{~L}_{22} \mathrm{Cl}_{4}\right]\left(\mathrm{ClO}_{4}\right)_{4} \cdot 2 \mathrm{H}_{2} \mathrm{O}$ tetrade. ${ }^{26}$ most prevalent oxidation state of indium and lutetium in aqueous solution is +3 . In comparison to transition metal ions, $\ln ($ III) and Lu(III) are relatively large, providing coordination numbers of typically 7-8 for In(III) complexes and 8-9 for Lu(IIII) complexes. For comparison, effective ionic radii of 8-coordinated complexes are 92 ppm for In(III), $98 \mathrm{ppm}$ for Lu(III) and $78 \mathrm{ppm}$ for Fe(III). ${ }^{46}$ Due to their hard Lewis acid character, Lu(III) and In(III), to a lesser extent, prefer chelators with hard Lewis bases such as carboxylate, phenolate or phosphonate. As a consequence, both form stable hydroxo complexes in water, which renders their radiolabelling more difficult and particularly challenging in the case of $\operatorname{In}\left(\mathrm{p} K_{\mathrm{a}}=4.0\right.$ for $\ln (I I I)$ and $\mathrm{p} K_{\mathrm{a}}=7.6$ for $\mathrm{Lu}(\mathrm{III})$ ). Moreover, because of a strong shielding of the $4 f$ orbitals, the coordination chemistry of lanthanides is essentially governed by electrostatic interactions and steric repulsion interactions.

The octadentate ligand $\mathrm{L}_{11}$ developed by Comba and coworkers and substituted with two picolinate pendant arms provides quantitative radiochemical yields (>99\%) with ${ }^{111} \mathrm{In}$ and ${ }^{177} \mathrm{Lu}$ at $10^{-7} \mathrm{M}$ concentration in water (Figure 19). ${ }^{47}$ Similarly to what have been observed with transition metal ions, coordination of the ligand to the Lu(III) is characterized by a well-resolved diastereotopic splitting of the methylene protons of the picolinic acid moieties. In the case of $\operatorname{In}($ III), broadening of the signals is observed, indicating a fluxional behaviour. The formation constants ( $\log K_{\mathrm{InL}}=24.39(6), \log K_{\mathrm{LuL}}=$ 8.51(3), $\left.\log K_{\mathrm{LuLH}}=12.60(22), \log K_{\mathrm{LuLH}_{2}}=16.35(11), \mathrm{L}=\mathrm{L}_{11}\right)$ have been determined by potentiometry. It appears that the complex stability of $\left[\mathrm{LuL}_{11}\right]^{+}(\mathrm{pM}=8.51(3))$ and $\left[\mathrm{InL}_{11}\right]^{+}(\mathrm{pM}=25.0)$ is rather low in comparison to other complexes with picolinate arms. Nevertheless, competition radiostability experiments with endogeneous ligands indicated very similar kinetic stabilities. Finally, radiolabelling of the actinide ${ }^{225} \mathrm{Ac}$ (III) was also achieved at room temperature by using $10^{-4} \mathrm{M}$ aqueous solutions of ligand $\mathrm{L}_{11}{ }^{2-}$.

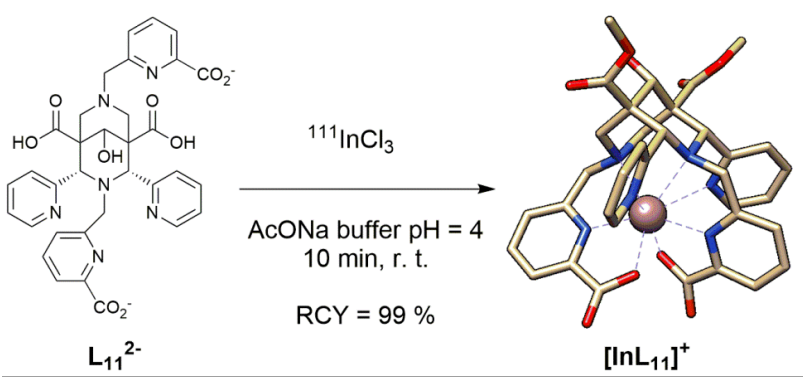

Figure 19: Radiolabelling of ligand $L_{11}$ with ${ }^{111}$ In with quantitative radiochemical yields (RCY) and corresponding $\mathrm{X}$ ray crystal structure. ${ }^{47}$

\section{Applications}

\section{Analgesic and antiarrhythmic agents}

Historically, $L_{1}$ was studied for pain relief because of its analgesic properties, i.e. as an inhibitor of the sensory nervous system's response resulting in a subjective pain sensation. In pharmacology, this response is defined as the nociceptive activity. $L_{1}$ was found to be a $\mathrm{K}$-opioid receptors (KOR) agonist. This means that it selectively 
recognises and activates KORs involved in nociception, consciousness, motor control and mood. ${ }^{48}$ Many studies have been done and have demonstrated the efficiency of this bispidone as an analgesic agent. In vitro, $L_{1}$ has shown, in opioid ligand binding and isolated organ assays, a great selective affinity and high agonist potency. Its strong antinociceptive properties have a potency comparable to morphine. In term of structural properties, the molecule has shown an almost full double protonation at $\mathrm{pH} 7.4$ located on the tertiary amine functions of the bicycle. The protonation of the amine N7 and the observed chair-boat conformation leads to the active conformation. This active conformation is characterised by an almost parallel orientation of a carbonyl group and a protonated $\mathrm{NH}$ function in conjunction with at least one aromatic ring. In a more recent study, docking of $L_{1}$ in KOR have been studied and have shown the formation of a salt bridge between a glutamate residue, the carbonyl oxygen atom of the bispidone and a serine residue, especially at the extracellular loops (Figure 20). ${ }^{49}$

Again, the observed double protonation of the bicycle amines leads to a switch of the conformation from a chair-chair to a chair-boat conformation. When the second nitrogen is protonated (N7), it leads to the formation of a second salt bridge between this latter and a glutamate residue. In addition, once the carbonyl group is protonated, the formation of an hemiaminal bond occurs. Both this formation and the presence of the two salt bridges explain the high affinity of $L_{1}$ for the KOR receptor and also a long duration of action of this agonist. Among other, a patent has been published in which they were using $L_{1}$ for treating vasomotor symptoms. To treat the vasomotor symptoms, this latter is used as an agonist towards KOR, in combination with a neurokine 3 receptor and a neurokine 1 receptor antagonists. ${ }^{50}$

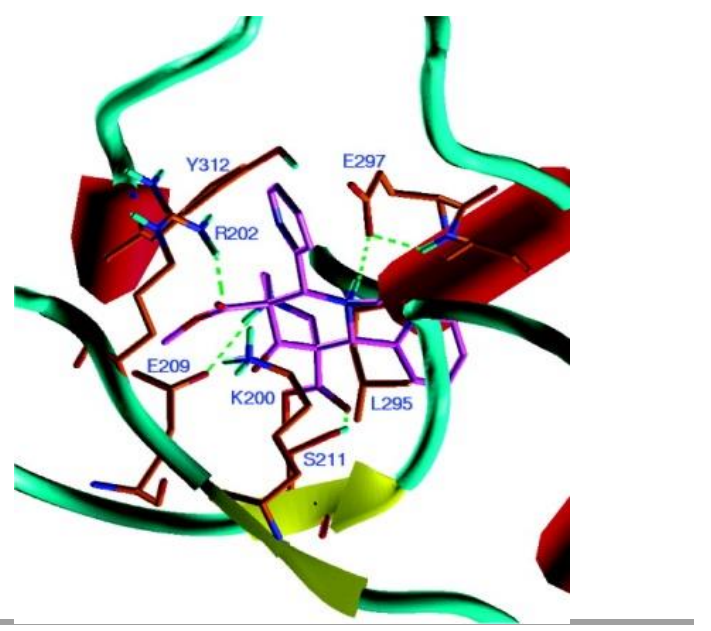

Figure 20: Docking arrangement of $L_{1}$ at a binding site of KOR between the extracellular loops two and three. Reproduced with permission from ref 49. Copyright 2019 American Chemical Society.

\section{Catalysis and oxygen bleaching agents}

Because bispidone basically offers a rigid and preorganized tetradentate coordination cavity, their coordination to $d$ transition metal cations results in an unsaturated coordination of the ligand and the possibility to play with the remaining coordination sites of the cations for activation of small molecules or for catalytic purposes. As an example, Börzel and co-workers reported the observation that $\mathrm{Cu}(\mathrm{II})$ bispidones based on simple structures with ligand $L_{1}$ reacted with dioxygen to form ( $\mu$-peroxo)dicopper(II) complexes stable in acetonitrile solutions at temperatures up to $250 \mathrm{~K}^{44}$ Intermetallic distances have been determined from X-ray diffraction structures in the solid state and amount to $d(\mathrm{Cu} 1, \mathrm{Cu} 2)=$ $6.4 \AA$ in $\left.\left[\mathrm{Cu}_{2}\left(\mathrm{~L}_{14}\right)\left(\mathrm{NCCH}_{3}\right)_{2}\right]\left(\mathrm{PF}_{6}\right)_{2}\right]$ and $7.6 \AA$ in the corresponding dinuclear $\mathrm{Cu}(\mathrm{II})$ complex. Considering the large interest in activation of molecular dioxygen in biological or industrial processes, the authors considered the possibility to further stabilize the dinuclear complex by bridging tow bispidine entities. They then synthesized an ethyl bridged bis-bispidone (ligand $\mathrm{L}_{14}$, Figure 21) which was shown to considerably stabilize the dioxygen product $\left[\mathrm{Cu}_{2} \mathrm{~L}\left(\mathrm{O}_{2}\right)\right]^{2+}$, which appeared to be stable at $298 \mathrm{~K}$ for almost one hour.

a)

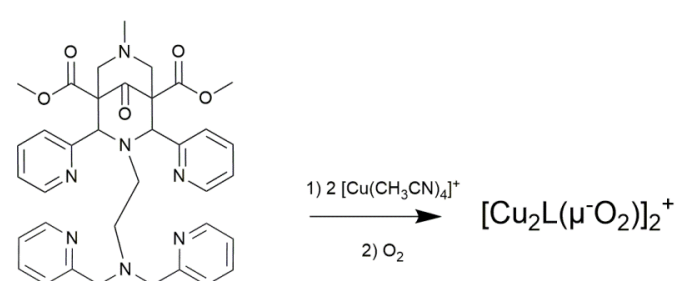

b)

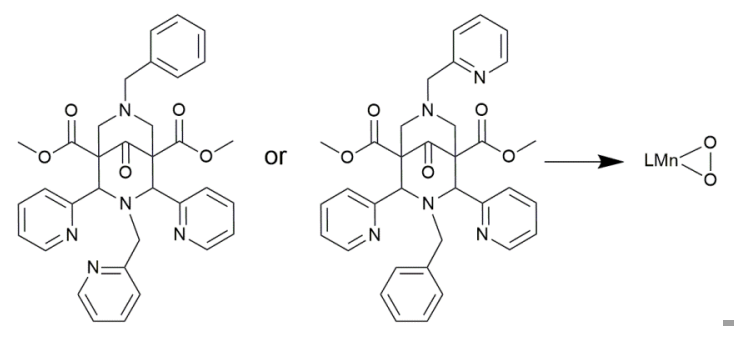

Figure 21: Synthesis of a bis-Cu(II) complex (a) and $\mathrm{Mn}$ (III) complexes (b) for activation of dioxygen. ${ }^{44}$

Activation of oxygen was also the interest in the work on $\mathrm{Mn}$ (III) complexes developed by Reinhard and co-workers for their use as catalyst for aldehyde deformylation reactions. ${ }^{51}$ Thanks to a very complete analysis based on spectroscopy, kinetic experiments with deuterated analogues, and computational studies, they were able to show that the $\mathrm{Mn}$ (III)-peroxo complex was able to remove the aldehyde functions and that the efficiency of the system was strongly related to the coordination sphere around the $\mathrm{Mn}$ (III) cations, and more particularly to the position of the pyridyl substitutions on the $R_{1}$ and $R_{2}$ positions (Figure $21 \mathrm{~b}$ ). Inverting the substitution pattern at $R_{1}$ and $R_{2}$ with a methyl or a pyridyl group on the same kind of bispidone ligands was shown to play a crucial role in the efficiency of $\mathrm{Fe}(\mathrm{III})$ catalysts for the epoxidation of cyclooctene. These Fe complexes have been shown to be effective catalyst within the frame of stain bleaching. Such catalysts have numerous applications in the paper-making or clothing industries, and might help to decrease the annual million metric tons of hydrogen peroxide used for bleaching application. ${ }^{52}$ 
By appending a bipyridyl moiety in position $\mathrm{R}_{2}$ of a bispidine, Comba and coworkers synthesized a mixed complex featuring a $\left[\mathrm{Ru}(\mathrm{bipy})_{3}\right]$ photosensitizing unit and a $\mathrm{Cu}(\mathrm{II})$-bispidine complex (Ligands $\mathrm{L}_{20}$ and $L_{21}$, Figure 8$) .{ }^{25}$ They were able to demonstrate that the combination lead to an active photocatalyst within the frame of aziridination of styrenes, while each unit alone was inefficient for this reaction. Lam and coworkers also played with the potentiality offered by the functionalisation of bispidines to introduce polyfluorinated alkyl chains in $R_{2}$ position or to alkylate the hydroxyl group of bispidols (ligands $L_{5}$ and $L_{6}$, Figure 5 ). ${ }^{20}$ They demonstrated that the fluorinated bispidines could be efficient green catalyst in different reactions such as oxidation of benzylic alcohols or of allylic positions, in the form of their $\mathrm{Cu}(\mathrm{II})$ complexes, or should also be used, free of metal, as proton sponge for the catalysis of Knoevenhagel condensations. They could also be combined to conduct a one pot/two steps oxidation/Knoevenhagel condensation reaction, and the catalyst could be readily recovered in high yields using fluorous solid phase extraction.

The rather straightforward synthesis of bispidines made them very attractive targets for large scale applications and some of them have been patented for applications as radical copolymerization agents of polyester resins or as curing agents for coatings. ${ }^{53}$

\section{Nuclear imaging and radiotherapy}

Radiometals such as ${ }^{64} \mathrm{Cu} /{ }^{67} \mathrm{Cu}$, and by extension ${ }^{111} \mathrm{In} /{ }^{177} \mathrm{Lu}$, are socalled theranostic pairs and have a high potential in terms of drug development and personalized medicine. The interest lies in the fact that the same ligand can be used for imaging (with positron emitting ${ }^{64} \mathrm{Cu}$ or single $\checkmark$ emission of ${ }^{111} \mathrm{In}$ ), dosimetry and evaluation of the therapeutic dose and for 8 -therapy (with ${ }^{67} \mathrm{Cu}$ or ${ }^{177} \mathrm{Lu}$ in this case). Whatever the metal ion used, there is a need in developing ligands which can fulfil the three following criteria: (i) fast complexation of the radiometal in aqueous solutions at $\mathrm{pM}$ to $\mathrm{nM}$ concentrations, at room temperature and at $\mathrm{pHs}$ close to physiological pH; (ii) a good in vivo kinetic inertness (towards reduction, transchelation and transmetalation reactions); (iii) a labelling function for coupling with targeting vectors. Criteria (i) and (ii) may seem contradictory. On the one hand, rigid macrocyclic ligands give highly thermodynamically and kinetic stable complexes but with slow kinetic formation, which may be prohibitive for the use of heat-sensitive targeting vectors such as antibodies. On the other hand, podants and linear ligands generally display fast complexation at ambient temperature but suffer from low kinetic stabilities. Only a handful of complexes can meet simultaneously the two criteria, bispidine derivatives being part of those. The application of 2,4-substituted bispidine ligands to radiopharmaceuticals has been reviewed by Tomassoli and Gündisch ${ }^{54}$ and more recently by Comba and coworkers. ${ }^{11}$

In particular, quantitative radiolabelling of ${ }^{64} \mathrm{Cu}$ is achieved after a few minutes at ambient temperature, in aqueous buffer, and with high specific activities. Radiochallenge experiments in plasma and with other competitors have proven a stability of the radiolabeled bispidines over a period up to $24 \mathrm{~h} .{ }^{11}$ The strong kinetic inertia of bispidine complexes is probably due to a combination of factors. First of all, $\mathrm{Cu}(\mathrm{II})$ complexes with ligands $\mathrm{L}_{12}{ }^{32} \mathrm{~L}_{9}{ }^{10} \mathrm{~L}_{7}$ and $\mathrm{L}_{8}{ }^{39}$ are formed at very low $\mathrm{pH}(95 \%$ or more at $\mathrm{pH}=2)$. As a consequence, acid-assisted dissociation pathway is strongly disfavoured. This is also true for $\left[\mathrm{InL}_{11}\right]^{+}$and, to a lesser degree, for $\left[\mathrm{LuL}_{11}{ }^{+}\right](>95 \%$ at $\mathrm{pH}$ $\approx 5.5) .{ }^{47}$ Another very important factor for $\mathrm{Cu}(\mathrm{II})$ complexes is the low reduction $\mathrm{Cu}(\mathrm{II}) \rightarrow \mathrm{Cu}(\mathrm{I})$ potential and the quasi-reversibility of the redox mechanism indicating the absence of release of $\mathrm{Cu}(\mathrm{I})$ even at low potential. $E_{\text {red }}$ as low as $-600 \mathrm{mV}$ (vs NHE) in water can be obtained (for $L_{9}$, Table 2 ), which is well below the reduction potential of biological reducing agents $(-400 \mathrm{mV})$.

The overall lipophilicity of the radiopharmaceutic agent can be tuned by controlling the charge of the complex as well as the hydrophobicity of the substituents. Bispidine complexes being rather hydrophobic, fast blood clearance through kidney and urine is observed with no accumulation in liver and bladder. ${ }^{11}$

Finally, conjugation with a bombesin targeting peptide allowed a clear visualization of human prostate cancer in PC-3 mice. ${ }^{28}$ This is due to the strong affinity of bispidine-bombesine conjugate for the gastrin-realeasing peptide receptor (GRPr) overexpressed in prostate tumours and as a consequence, a good uptake in tumour
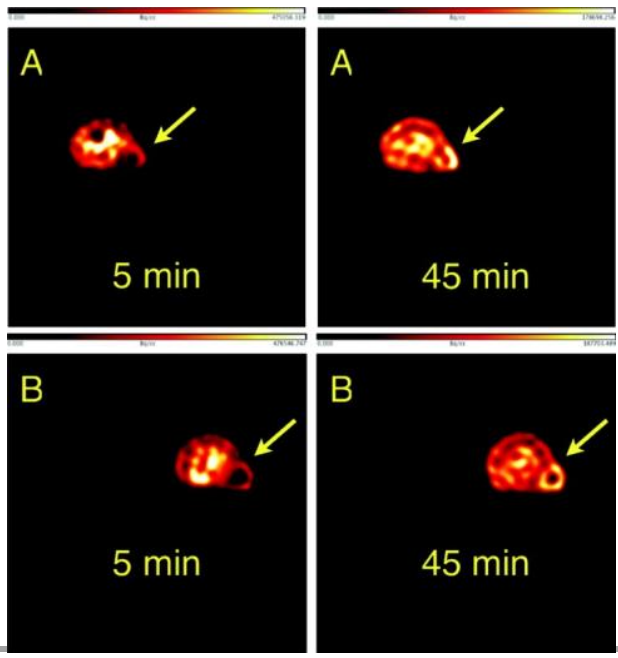

Figure 22: Coronal sections of a small animal PET study of two $\mathrm{PC}-3$ tumor-bearing mice $(\mathrm{A}, \mathrm{B})$ after single intravenous application of ${ }^{64} \mathrm{Cu}$-bombesine-conjugate at 5 and $45 \mathrm{~min}$. The arrow shows the tumor. Reproduced with permission from ref 28. Copyright 2019 American Chemical Society.

tissues (Figure 22).

\section{Conclusions}

Originally inspired by nature, bispidine derivatives have given rise to applications in a wide variety of coordination complexes involving different types of metal ions of the $s, p d$ and $f$ block metallic elements. In particular, modifications of the ligand backbone can be used to tune the denticity of the ligand in order to accommodate coordination numbers from $\mathrm{CN}=5$ to $\mathrm{CN}=9$ with a large variety of coordination environments.

Various functionalisation strategies have been developed to introduce substituents at $\mathrm{C2}, \mathrm{C} 4, \mathrm{~N} 3$ and N7 but also on other position $\left(\mathrm{R}^{\prime}, \mathrm{OH}\right)$ while controlling the stereochemistry. 
The combination of a rigid ligand, an elastic coordination sphere and a fine-tuning of the ligand basicity and ligand field has important repercussions on the thermodynamic stability, metal selectivity, redox properties and spin configuration. This has led to appealing properties as catalysts for the activation of small molecules. Mono and polynuclear complexes with unique magnetic properties have also been obtained from a fine tuning of the ligand field, which opens up promising prospects for bispidine architectures. Finally, $\mathrm{Cu}$ (II) complexes with bispidol derivatives are strong candidates for biomedical applications such as PET-imaging or sensing, because of their remarkable kinetic inertness, fast complexation kinetics and low reduction potentials. However, quantitative labelling in bio-friendly conditions may not always be possible. Hence, improving the functionalisation pathways is the key to obtain new bioconjugates for specific applications.

\section{Conflicts of interest}

There are no conflicts to declare.

\section{Acknowledgements}

The authors acknowledge CNRS for financial support together with the French National Research Agency (ANR) (MANGA project $n^{\circ} 18$ CE18-0008-03) for funding of M.S.

\section{Notes and references:}

1 J. Stenhouse, Ann. Chem. Pharm., 1851, 1-5.

2 C. Mannich and F. Veit, Ber. dtsch. Chem. Ges. A/B, 1935, 68, 506512.

3 E. E. Smissman and P. C. Ruenitz, J. Med. Chem., 1976, 19, 184186.

4 A. Borsodi, S. Benyhe, U. Holzgrabe, Á. Márki and C. Nachtsheim, Regulatory Peptides, 1994, 54, 27-28.

5 P. Comba, M. Kerscher and W. Schiek, in Progress in Inorganic Chemistry, ed. K. D. Karlin, John Wiley \& Sons, Inc., 2007, pp. 613704.

6 R. Haller and H. Unholzer, Arch. Pharm., 1972, 305, 855-863.

7 R. Caujolle, A. Lattes, J. Jaud and J. Galy, Acta Crystallographica Section B Structural Crystallography and Crystal Chemistry, 1981, 37, 1699-1703.

8 U. Kuhl, A. Cambareri, C. Sauber, F. Sörgel, R. Hartmann, H. Euler, A. Kirfel and U. Holzgrabe, J. Chem. Soc., Perkin Trans. 2, 1999, 2083-2088.

9 T. Legdali, A. Roux, C. Platas-Iglesias, F. Camerel, A. M. Nonat and L. J. Charbonnière, J. Org. Chem., 2012, 77, 11167-11176.

10 R. Gillet, A. Roux, J. Brandel, S. Huclier-Markai, F. Camerel, O. Jeannin, A. M. Nonat and L. J. Charbonnière, Inorg. Chem., 2017, 56, 11738-11752.

11 P. Comba, M. Kerscher, K. Rück and M. Starke, Dalton Trans., 2018, 47, 9202-9220.

12 A. Roux, A. M. Nonat, J. Brandel, V. Hubscher-Bruder and L. J. Charbonnière, Inorg. Chem., 2015, 54, 4431-4444.

13 P. Comba, H. Wadepohl and S. Wiesner, Eur. J. Inorg. Chem., 2011, 2610-2615.

14 P. Comba, M. Morgen and H. Wadepohl, Inorg. Chem., 2013, 52 , 6481-6501.

15 N. A. Barnes, A. T. Brooker, S. M. Godfrey, P. R. Mallender, R. G. Pritchard and M. Sadler, Eur. J. Org. Chem., 2008, 1019-1030.
16 S. Norrehed, M. Erdélyi, M. E. Light and A. Gogoll, Org. Biomol. Chem., 2013, 11, 6292-6299.

17 T. Siener, U. Holzgrabe, S. Drosihn and W. Brandt, J. Chem. Soc., Perkin Trans. 2, 1999, 1827-1834.

18 C. Bleiholder, H. Börzel, P. Comba, R. Ferrari, M. Heydt, M. Kerscher, S. Kuwata, G. Laurenczy, G. A. Lawrance, A. Lienke, B. Martin, M. Merz, B. Nuber and H. Pritzkow, Inorg. Chem., 2005, 44, 8145-8155.

19 J. L. Kolanowski, E. Jeanneau, R. Steinhoff and J. Hasserodt, Chem. Eur. J., 2013, 19, 8839-8849.

20 W. J. Ang, Y. S. Chng and Y. Lam, RSC Adv., 2015, 5, 8141581428.

21 P. Comba, L. Grimm, C. Orvig, K. Rück and H. Wadepohl, Inorg. Chem., 2016, 55, 12531-12543.

22 P. Comba, A. Hauser, M. Kerscher and H. Pritzkow, Ang. Chem. Int. Ed., 2003, 42, 4536-4540.

23 H. Börzel, P. Comba, K. S. Hagen, M. Kerscher, H. Pritzkow, M. Schatz, S. Schindler and O. Walter, Inorg. Chem., 2002, 41, 54405452.

24 U. Kuhl, W. Englberger, M. Haurand and U. Holzgrabe, Arch. Pharm. Pharm. Med. Chem., 2000, 226-230.

25 C. Busche, P. Comba, A. Mayboroda and H. Wadepohl, Eur. J. Inorg. Chem., 2010, 1295-1302.

26 M. Grosshauser, P. Comba, J. Y. Kim, K. Ohto, P. Thuéry, Y. H. Lee, Y. Kim and J. Harrowfield, Dalton Trans., 2014, 43, 56625666.

27 R. Haller and H. Unholzer, Arch. Pharm. Ber. Dtsch. Pharm. Ges., 1971, 654-659.

28 S. Juran, M. Walther, H. Stephan, R. Bergmann, J. Steinbach, W. Kraus, F. Emmerling and P. Comba, Bioconjugate Chem., 2009, 20, 347-359.

29 H. Stephan, M. Walther, S. Fähnemann, P. Ceroni, J. K. Molloy, G. Bergamini, F. Heisig, C. E. Müller, W. Kraus and P. Comba, Chem. Eur. J., 2014, 20, 17011-17018.

30 P. Parthiban, G. Aridoss, P. Rathika, V. Ramkumar and S. Kabilan, Bioorg. Med. Chem., 2009, 19, 6981-6985.

31 D. Brox, P. Comba, D.-P. Herten, E. Kimmle, M. Morgen, C. L. Rühl, A. Rybina, H. Stephan, G. Storch and H. Wadepohl, J. Inorg. Biochem., 2015, 78-83.

32 A. Roux, R. Gillet, S. Huclier-Markai, L. Ehret-Sabatier, L. J. Charbonnière and A. M. Nonat, Org. Biomol. Chem., 2017, 15, 1475-1483.

33 R. Haller, Arch. Pharm. Ber. Dtsc. Pharm. Ges., 1969, 302, 113118.

34 P. Comba, B. Nuber and A. Ramlow, J. Chem. Soc., Dalton Trans., 1997, 347-352.

35 P. Comba, B. Kanellakopulos, C. Katsichtis, A. Lienke, H. Pritzkow and F. Rominger, J. Chem. Soc., Dalton Trans., 1998, 3997-4002.

36 M. Atanasov, P. Comba, S. Helmle, D. Müller and F. Neese, Inorg. Chem., 2012, 51, 12324-12335.

37 P. Comba, M. Kerscher, M. Merz, V. Müller, H. Pritzkow, R. Remenyi, W. Schiek and Y. Xiong, Chem. Eur. J., 2002, 8, 57505760 .

38 K. Born, P. Comba, R. Ferrari, G. A. Lawrance and H. Wadepohl, Inorg. Chem., 2007, 46, 458-464.

39 P. Comba, L. Grimm, C. Orvig, K. Rueck and H. Wadepohl, Inorg. Chem., 2016, 55, 12531-12543.

40 H. Börzel, P. Comba, K. S. Hagen, C. Katsichtis and H. Pritzkow, Chem. Eur. J., 2000, 6, 914-919.

41 J. Bautz, P. Comba and L. Que, Inorg. Chem., 2006, 45, 70777082. 
42 A. E. Anastasi, A. Lienke, P. Comba, H. Rohwer and J. E. McGrady, Eur. J. Inorg. Chem., 2007, 65-73.

43 P. Comba, H. Rudolf and H. Wadepohl, Dalton Trans., 2015, 44, 2724-2736.

44 M. Atanasov, C. Busche, P. Comba, F. El Hallak, B. Martin, G. Rajaraman, J. van Slageren and H. Wadepohl, Inorg. Chem., 2008, 47, 8112-8125.

45 H. Börzel, P. Comba, C. Katsichtis, W. Kiefer, A. Lienke, V. Nagel and H. Pritzkow, Chem. Eur. J., 1999, 5, 1716-1721.

46 R. D. Shannon, Acta Cryst. A, 1976, 32, 751-767.

47 P. Comba, U. Jermilova, C. Orvig, B. O. Patrick, C. F. Ramogida, K. Rueck, C. Schneider and M. Starke, Chem.-Eur. J., 2017, 23, 15945-15956.

48 B. Kögel, T. Christoph, E. Friderichs, H.-H. Hennies, T. Matthiesen, J. Schneider and U. Holzgrabe, CNS Drug Reviews, 1998, 4, 54-70.

49 U. Holzgrabe and W. Brandt, J. Med. Chem., 2003, 46, 13831389.

50 R. A. Steiner, C. Chavkin, D. K. Clifton, S. Reed, V. Navarro, WO2014089019 A1, 2014.

51 F. G. Cantú Reinhard, P. Barman, G. Mukherjee, J. Kumar, D. Kumar, D. Kumar, C. V. Sastri and S. P. de Visser, J. Am. Chem. Soc., 2017, 139, 18328-18338.

52 R. Hage and A. Lienke, Ang. Chem. Int. Ed., 2006, 45, 206-222.

53 J. F. G. A. Jansen, I. Hilker, G. J. E. Hensen, D. S. R. A. Silvestre, WO2013083630 A1, 2013.

54 I. Tomassoli, D. Gündisch, Curr. Top. Med. Chem., 2016, 16, 1314-1342. 